\title{
Harvey Cushing and pituitary Case Number 3 (Mary D.): the origin of this most baffling problem in neurosurgery
}

\author{
José María Pascual, MD, PhD, ${ }^{1}$ and Ruth Prieto, MD, PhD² \\ 'Department of Neurosurgery, La Princesa University Hospital; and 2Department of Neurosurgery, Puerta de Hierro University \\ Hospital, Madrid, Spain
}

\begin{abstract}
From the very beginning of his career, Harvey Williams Cushing (1869-1939) harbored a deep interest in a complex group of neoplasms that usually developed at the infundibulum. These were initially known as "interpeduncular" or "suprasellar" cysts. Cushing introduced the term "craniopharyngioma" for these lesions, which he believed represented one of the most baffling problems faced by neurosurgeons. The patient who most influenced Cushing's thinking was a 16-year-old seamstress named "Mary D.," whom he attended in December 1901, exactly the same month that Alfred Fröhlich published his seminal article describing an adiposogenital syndrome in a young boy with a pituitary cyst. Both Cushing's and Fröhlich's patients showed similar symptoms caused by the same type of tumor. Notably, Cushing and Fröhlich had met one another and became good friends in Liverpool the summer before these events took place. Their fortunate relationship led Cushing to realize that Fröhlich's syndrome represented a state of hypopituitarism and provided a useful method of diagnosing interpeduncular cysts. It is noteworthy that Cushing's very first neurosurgical procedure on a pituitary tumor was performed in the case of Mary D.'s "interpeduncular cyst," on February 21, 1902. Cushing failed to remove this lesion, which was later found during the patient's autopsy. This case was documented as Pituitary Case Number 3 in Cushing's masterpiece, The Pituitary Body and Its Disorders, published in 1912. This tumor was considered "a teratoma"; however, multiple sources of evidence suggest that this lesion actually corresponded to an adamantinomatous craniopharyngioma. Unfortunately, the pathological specimens of this lesion were misplaced, and this prompted Cushing's decision to retain all specimens and documents of the cases he would operate on throughout his career. Accordingly, Mary D.'s case crystallized the genesis of the Cushing Brain Tumor Registry, one of Cushing's major legacies to neurosurgery. In this paper the authors analyze the case of Mary D. and the great influence it had on Cushing's conceptions of the pituitary gland and its afflictions, and on the history of pituitary surgery.
\end{abstract}

http://thejns.org/doi/abs/10.3171/2016.2.FOCUS1592

KEY WORDS craniopharyngioma; Harvey Cushing; history; pituitary surgery; hypothalamus; infundibulum; teratoma

All in all, these cases offer the most baffling problem which confronts the neurosurgeon.

$$
\text { - Harvey Williams Cushing, } 1932^{30}
$$

In December 1901, shortly after his return to Johns Hopkins from a lengthy stay in Europe, Harvey Williams Cushing (1869-1939) (Fig. 1) attended a young patient named Mary Donnelly ("Mary D."). She was an obese and sexually undeveloped 16-year-old woman who suffered from severe headaches caused by a rare type of cyst that had developed above the pituitary gland. This patient was Cushing's first pituitary case. At that time, Cushing was ignorant of the publication of a very similar case by a
Viennese physician he had met only a few months earlier in Liverpool, Alfred Fröhlich (1871-1953). In his paper, published around the same time that Cushing took care of Mary D., Fröhlich paid particular attention to the occurrence of sexual infantilism and obesity in association with large pituitary tumors..$^{41}$ Unaware of Fröhlich's report of the adiposogenital syndrome, Cushing was unable to connect Mary D.'s symptoms to the presence of a pituitary tumor. In a desperate attempt to find and remove her cerebral tumor, he operated on Mary D. three times without success, between February and March 1902. ${ }^{33}$ In the end, a large interpeduncular cyst originating in the infundibulum and tightly attached to the third ventricle floor was 


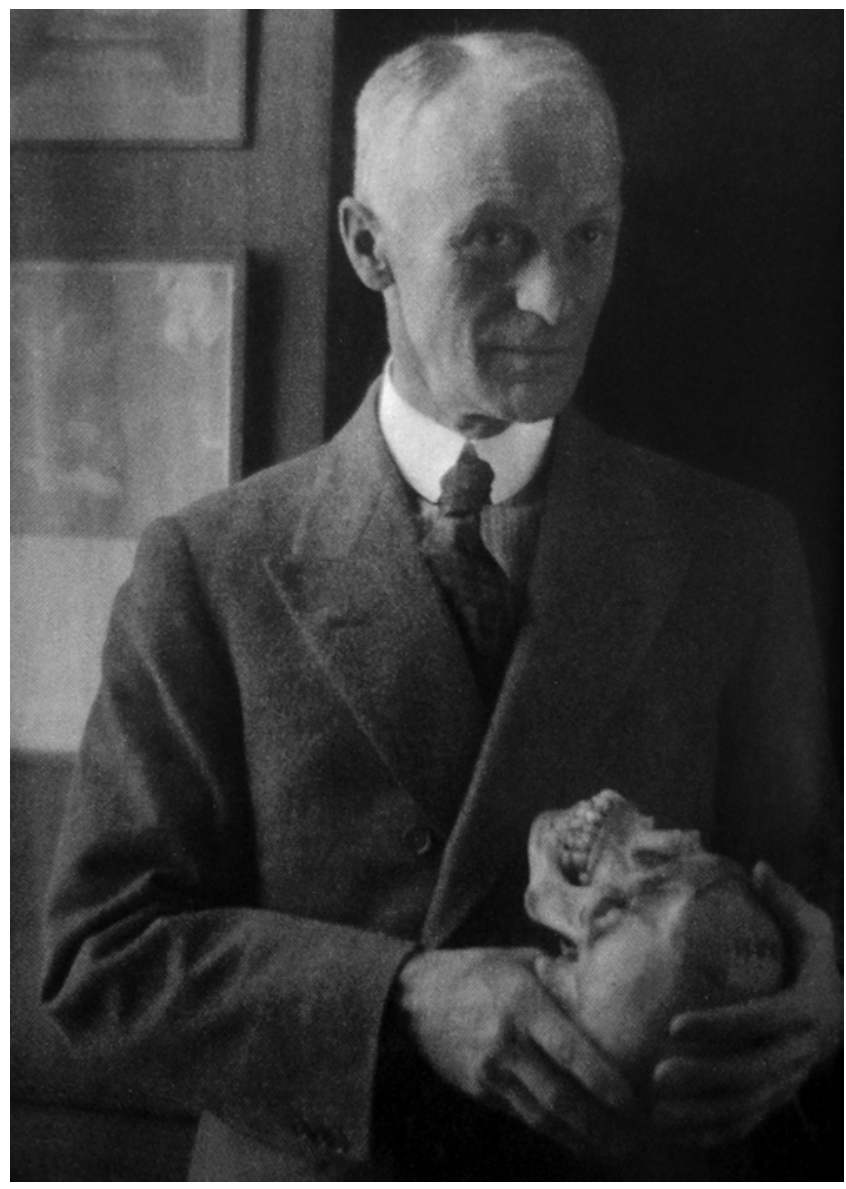

FIG. 1. Portrait of Harvey Williams Cushing (1869-1939) holding a skull in his office, by Doris Ullman, 1920s. From Wikimedia Commons.

found during Mary D.'s autopsy. Accurate pathological diagnosis of this tumor could not be confirmed because the tumor specimen was misplaced, an incident that triggered Cushing's resolution to keep the records and pathological specimens of all his operative cases. ${ }^{22,94,95}$ Multiple sources of evidence point to the fact that Mary D.'s tumor was actually a craniopharyngioma (CP), the current term in use introduced by Cushing in 1930 to replace the old category of interpeduncular or suprasellar cyst. ${ }^{25}$

In retrospect, Mary D.'s case could reasonably be nominated, ironically, for admission to both the list of most famous and most infamous patients in the history of pituitary surgery. The tumor represented Cushing's first failed neurosurgical approach to a pituitary tumor, yet this case stimulated his compelling interest in the pituitary gland and definitely influenced his decision to pursue a career as a pituitary surgeon. ${ }^{43,49}$ The indelible impression the case of Mary D. left on Cushing culminated in 1912 with his publication of the monograph The Pituitary Body and Its Disorders. ${ }^{31}$ In this book, Mary D.'s interpeduncular tumor was recorded as Pituitary Case III (roman numerals in the original). This type of tumor provided a clinical model to conceptualize the separation of hypophyseal and hypothalamic functions and influenced the development of the new field of neuroendocrinology. ${ }^{1,2,5,44,50,65}$ Finally, this case was also instrumental in the creation of the Brain
Tumor Registry, one of Cushing's major legacies to neurosurgery and neuropathology. ${ }^{22,94,95}$ The history of pituitary surgery owes much to Mary D. and her interpeduncular tumor. The story of this very special lesion, the noteworthy bond it had with the development of Cushing's strategies for the diagnosis and treatment of $\mathrm{CP}$, and the great influence it had on Cushing's long-lasting devotion to the field of pituitary physiology and surgery is the main focus of this article.

\section{Elucidating Mary D.'s Syndrome: The Significant Influence of the Cushing- Fröhlich Relationship on the Birth of Neuroendocrinology}

The birth of neuroendocrinology can be dated to the years 1900-1902, when 3 young patients showing a particular syndrome of adiposity and sexual infantilism were assessed, respectively, in Paris, Vienna, and Baltimore. ${ }^{1,2,68}$ In 1900, the French neurologist Joseph Babinski (1857-1932) was the first author to report the association of sexual infantilism and obesity observed in an adolescent with an epithelial tumor, whose histological features resembled those of adamantinomas of the jaw, expanding at the base of the brain (Fig. 2), ${ }^{4,73}$ Subsequently, it was Alfred Fröhlich (1871-1953) who paid particular attention to this "adipose-genital" syndrome in 1901, after examining a 14-year-old boy with this condition (Fig. 3). ${ }^{41}$ At the time of his report, Fröhlich was unable to recognize the nature or extent of the pituitary tumor causing the sexual and metabolic symptoms in his patient. The third historically "famous" patient showing the typical symptoms of Fröhlich's syndrome was Mary D., who was assessed at Johns Hopkins by the legendary American father of neurosurgery, Harvey Cushing, in December 1901..31,33

Mary D. was attended by Cushing for the first time in December 1901 and operated on unsuccessfully three times between February and March 1902. Cushing did not provide a written account of the case until 1906, after he recognized the same clinical syndrome of optic atrophy and sexual infantilism in another patient. ${ }^{33}$ Cushing listed this first verified, surgically treated pituitary tumor as Case Number III in The Pituitary Body and Its Disorders, a work that included a thorough clinical account of his series of pituitary cases to $1912 .{ }^{31}$ The reason for this case being numbered in the third position is because it was classified along with other pituitary lesions characterized by neighboring symptoms, or symptoms associated with anatomical distortions of structures adjacent to the tumor. ${ }^{31,84}$ We prepared this summary of the case by combining the set of data available in the 1906 report and that of the 1912 pituitary monograph.

\section{Clinical History}

On December 12, 1901, Mary D., a 16-year-old seamstress, entered Dr. Osler's Service at Johns Hopkins Hospital complaining of back pain, dizziness, and headache. She had never menstruated nor developed sexually. For a month before admission she noticed failing eyesight, with "dark spots" obscuring her vision. On physical examina- 

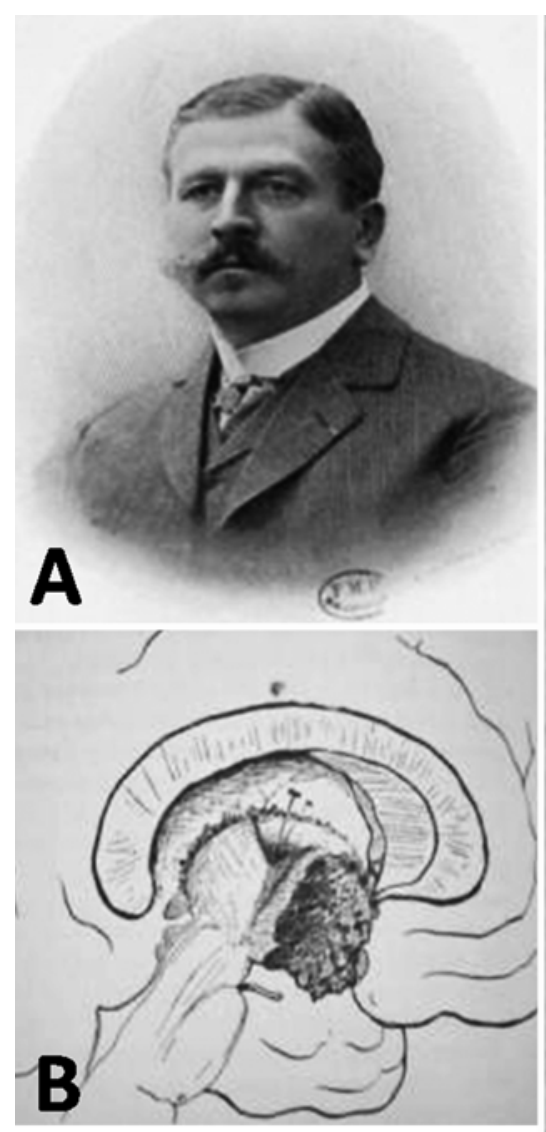

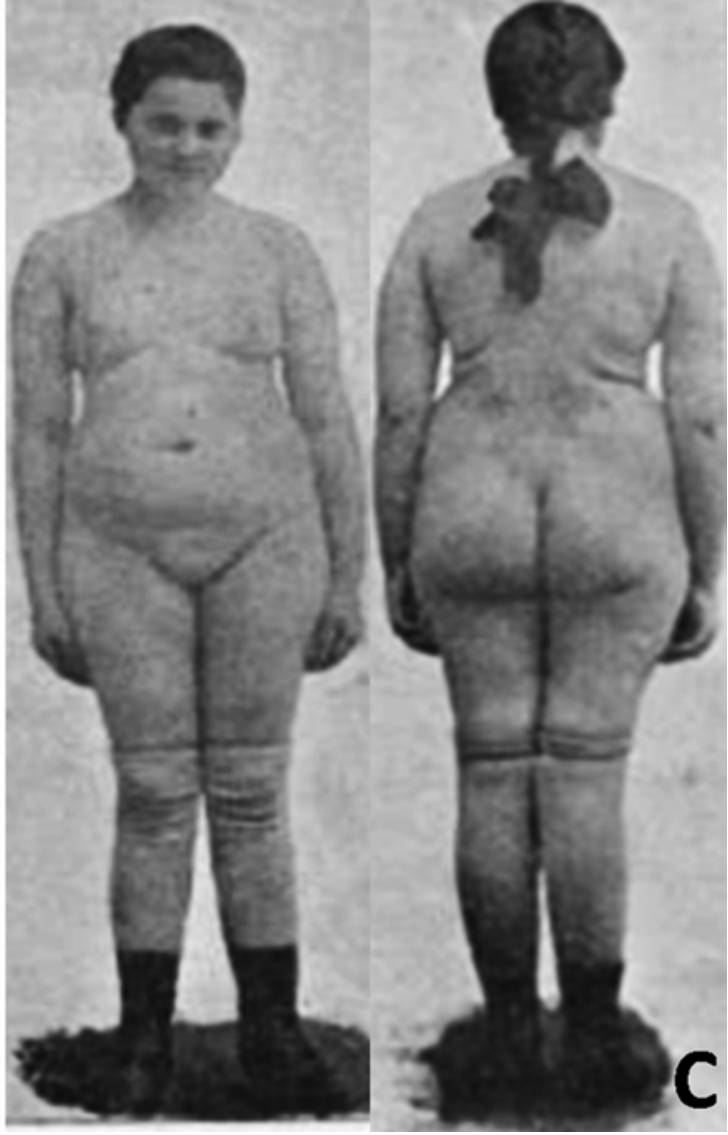

FIG. 2. A: Joseph Babinski (1857-1932), French neurologist who described the clinical case of a 17-year-old girl with obesity and amenorrhea, the characteristic symptoms of Fröhlich's syndrome. B: Illustrations of this tumor found at necropsy by Babinski and reported by Onanoff in his PhD thesis. The tumor corresponded to an infundibulo-tuberal $\mathrm{CP}$ replacing the third ventricle floor. $\mathrm{C}$ : Pictures of the young girl who died of a third ventricle tumor. Mary D's age and physical appearance closely matched those of Babinski's patient. B and C: From Babinsky: Rev Neurol 8:531-533, 1900.
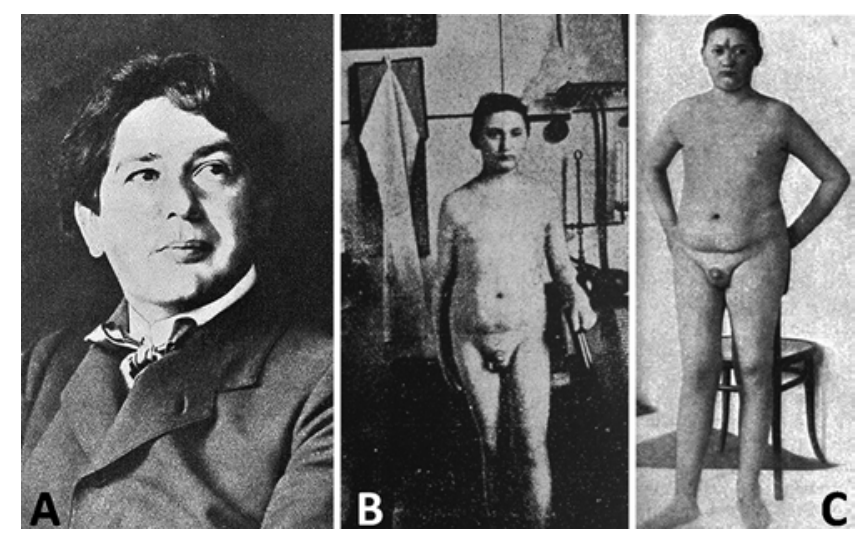

FIG. 3. A: Alfred Fröhlich (1871-1953). Picture published in New York in 1922. B: Fröhlich's patient at 14 years of age, in 1901. From Fröhlich: Wien Klin Rundschau 15:883-886, 906-908, 1901. C: Fröhlich's patient after surgery performed by Anton von Eiselsberg in June 1907. Note the scar on the nose produced by the upper transnasal-transsphenoidal surgical approach. From Biedl: Innere Sekretion. Ihre Physiologischen Grundlagen und Ihre Bedeutung für die Pathologie, Urban \& Schwarzenberg, 1913. tion the patient appeared well nourished, though undersized (4 feet, 8 inches). Her breasts were undeveloped and she showed a scant growth of axillary and pubic hair. Her mental development was childish. The waxy, smooth skin over the abundant adipose panniculus made it seem that the subcutaneous tissues were edematous. Vision was normal, although on December 24th a suspicious blurring of the nasal half of the discs was recorded on examination. For 2 months after her admission the patient was closely monitored. Ophthalmoscopic examination was negative until February 12, when a mild pallor of the optic nerves with low-degree choked discs (superimposed edema) was found in addition to shrinkage of the visual fields. The diagnosis of an intracranial mass was then suspected. From this time on, the patient's condition progressively worsened to the point that she remained in a more or less stuporous condition much of the time. Because of the rapid deterioration of her visual status and the progressive swelling of the discs, the neurologist Dr. H. M. Thomas considered, on February 18th, that the headaches and other symptoms of the patient were characteristic of an intracranial growth. He advised that she should be transferred to the surgical ward for an exploratory operation. 


\section{Surgical Procedures}

Cushing's surgical procedures in this case are fully described in his 1906 report,,$^{33}$ whereas in his 1912 monograph he made only a passing reference to the subject, which he defined as "three futile exploratory operations with the only purpose to disclose an internal hydrocephalus." 31 The first procedure was performed on February 21, 1902, and consisted of an exploratory frontoparietotemporal craniotomy, which was performed on the left side, leaving the dura opened (Fig. 4A and B). ${ }^{27}$ The second procedure, performed on March 8, reproduced the initial craniectomy over the right hemisphere. The same bulging brain condition was found and again the bone flap had to be removed; the dura was again left open. Following this operation the patient improved greatly, and by the 3rd postoperative day the papilledema had almost completely faded from the disc and retina of each eye. Due to the development of some ataxic symptoms, a third surgical intracranial exploration was attempted. On March 17, Cushing performed a suboccipital craniectomy and an exposure of the cerebellum, which proved negative (Fig. 4C). A short time after the operation the patient's condition worsened rapidly. She became mentally dim and lethargic, and at the same time her brain protrusions enlarged and became tense. She remained comatose until 6 weeks later, when death occurred from inanition and inhalation pneumonia. Cushing thought that the reason for the rapid fatal ending was the cerebellar protrusion after suboccipital decompression, which would have caused some dislocation of the tumor, with obstruction of the third ventricle and accumulation of CSF in the ventricles of both hemispheres. He concluded by acknowledging that the last surgical procedure was, in the end, "a meddlesome and disastrous operation." 33

\section{Autopsy}

The autopsy was performed by Dr. W. G. MacCallum on May 1, 1902. Upon removal of the brain, a hard, nodular tumor mass, the size of a golf ball, was found $o c$ cupying the infundibular space and the tuber cinereum [author's italics] between the crura, the optic chiasm, and the third ventricle, and extending up as far as the corpus callosum, as can be seen in a careful drawing done by Cushing (Fig. 5). It had dislocated the optic chiasm, optic tracts, and mammillary bodies by compression alone. The growth was found to overlie the pituitary body, which was small and flattened but anatomically intact. On separation of the hemispheres and division of the corpus callosum from above, the growth was found to project into the third ventricle under the thinned, stretched layer of the third ventricle floor. The foramina of Monro were both greatly dilated, as were the lateral ventricles. Examination of sections of the tumor showed it to be a mixed tumor containing cartilage, bone cells, myxomatous tissue, and tissue cells of various other sorts. It was pronounced a teratoma by Dr. William H. Welch (1850-1934), head of the Department of Pathology at Johns Hopkins. Unfortunately, no histological study was made of the pituitary body, and the gland has since been lost.

In the lecture Harvey Cushing delivered on January 19, 1933, to the New York Academy of Medicine, under the title Dyspituitarism Twenty Years Later, he recalled the events that motivated his original interest in the field of pituitary gland physiology and the surgical treatment of pituitary tumors. ${ }^{26}$ Cushing judged that the genesis of his curiosity was largely influenced by his first encounter with Alfred Fröhlich at Sherrington's laboratory in Liverpool and their common observations of the same type of pituitary tumor (an infundibular CP) described in an article published by Joseph Babinski (Fig. 2) ${ }^{4,77}$ :

I scarcely recall what first led us, soon after the opening of the Hunterian Laboratory in Baltimore in 1905, to attack such an uncompromising problem. Alfred Fröhlich and I had been co-workers in Sherrington's laboratory in Liverpool in 1900, in which year, unknown to us, Babinski had reported under the title "Tumor of the Pituitary Body without acromegaly" the case of a girl of 17 showing at autopsy arrested development of the organs of generation. ${ }^{36}$

It is interesting to note how Cushing mistakenly recalls the year 1900 as the time of his meeting with Fröhlich (actually it occurred in 1901), in the same year Babinski published his case. Toward the end of the long sojourn

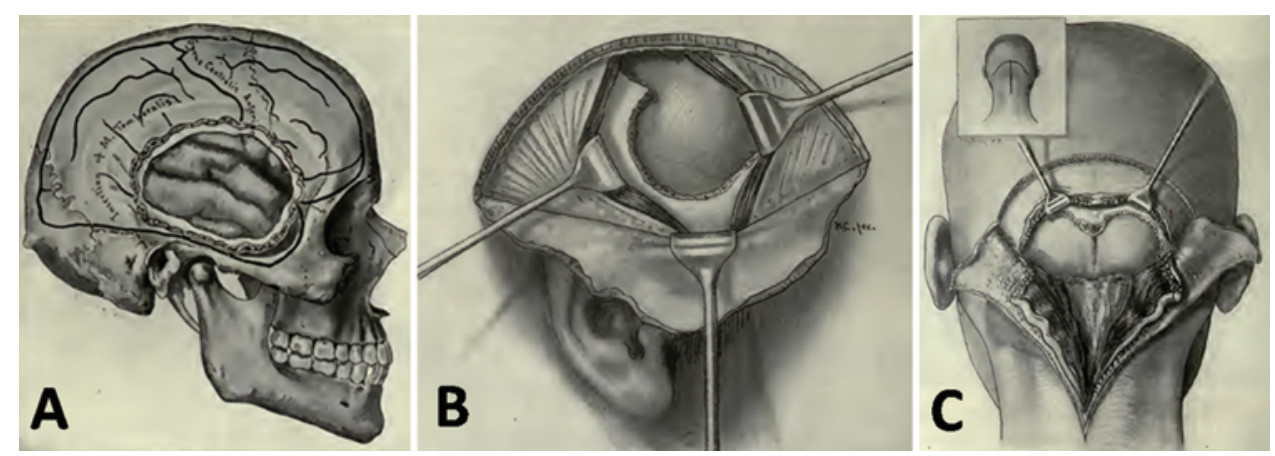

FIG. 4. Surgical procedures used by Harvey Cushing to explore Mary D's interpeduncular tumor. A: Subtemporal decompression. Sketch showing the relation of the bone defect to the underlying cortex and the area of the latter, which has herniated through the bone defect. B: Sketch of the intermusculotemporal field of the operation, showing partial exposure of subtemporal bone. This procedure was performed bilaterally in 2 surgical stages to reduce the high intracranial pressure. C: Sketch demonstrating suboccipital craniectomy showing author's "cross-bow" incision. This procedure was the third (futile) operation performed upon Mary D. by Cushing to explore the presumed presence of a cerebellar lesion. From Cushing: "Surgery of the head," in Keen WW (ed.): Surgery. Its Principles and Practice, W.B. Saunders Company, 1911. 


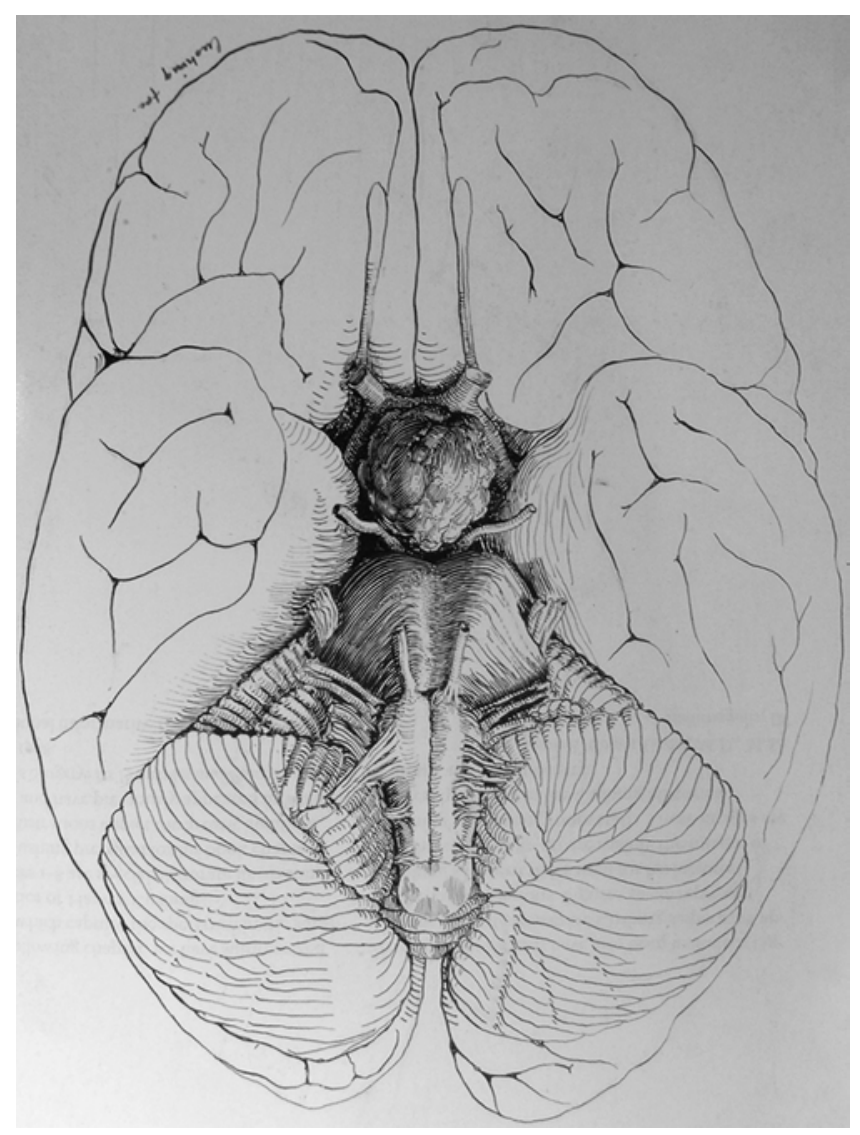

FIG. 5. Drawing of Mary D.'s interpeduncular cyst, made by Harvey Cushing at the time of the autopsy. Cushing's hand-written annotation at the bottom of the sketch (stored at the Harvey Cushing Brain Tumor Registry at Yale University, New Haven) says, "Drawing, of base of brain and tumor (Case I) from sketch of the tissues made at the time of the autopsy." Cushing remarks in the legend that this tumor corresponds to his first case of intracranial tumor surgically treated at Johns Hopkins. The case was finally numbered as "Case III" in Cushing's monograph The Pituitary Body and Its Disorders. From Cushing: J Nerv Ment Dis 33:704-716, 1906.

Cushing spent in Europe during the summer of 1901, he stayed briefly in Liverpool, where he assisted Charles Sherrington (1857-1952) in experiments in cortical localization before returning to Baltimore. At that time, in July 1901, Cushing met Alfred Fröhlich (1871-1953) (Fig. 3A), a young physician who had recently come to Sherrington's laboratory from Vienna with his young wife. Cushing developed a great fondness for Alfred Fröhlich. The two young physicians assisted Sherrington in some extraordinary cerebral stimulation experiments performed on large primates, including an orangutan, a chimpanzee, and a gorilla. ${ }^{12,43}$ They even formed a group of friends called "The Manx Club," with the purpose of taking trips in their spare time. This seemingly fortuitous encounter set off a chain of events that led to the birth of a new field of medicine, neuroendocrinology. Even more importantly, it gave rise to the development of pituitary surgery, one of the first scientifically developed fields of neurosurgery.

Barely 2 months after Fröhlich returned to Vienna, on September 23, 1901, a young boy with a mysterious assort- ment of symptoms consisting of headache, severe visual deterioration, sexual underdevelopment, feminine obesity, and a peculiar "childish" behavior came to the attention of the Viennese physician (Fig. 3B). This patient became the focal point of the important article published by Fröhlich in December 1901, which reported on a new syndrome associated with a rare type of tumor involving the pituitary gland. ${ }^{41}$ Meanwhile, Harvey Cushing had returned to Johns Hopkins, the institution where he intended to establish a career in neurological surgery. ${ }^{12,43,49}$ Although Johns Hopkins Hospital had a large outpatient department attending neurological afflictions, the major obstacle to developing a neurosurgery department was the inadequate supply of surgical patients..$^{49}$ It was William Osler (1849-1919), the first Physician-in-Chief of the hospital and Cushing's intimate friend and mentor, who handed Cushing his first "neurosurgical" case, a young woman called Mary Donnelly, who was admitted to Johns Hopkins on December 12, 1901. ${ }^{12,26,44}$ Unaware at the time of Fröhlich's report, Cushing was about to see a patient showing symptoms identical to those manifested in Frohlich's case.

It is an extraordinary coincidence that Cushing's first verified intracranial tumor case corresponded to a patient manifesting the same symptoms and harboring the same type of tumor as Fröhlich's patient. It is even more remarkable that both doctors had just met one another in England, just before departing to their home institutions where they had the opportunity to assess their respective "pituitary" cases within a very short time interval. The fact that they became colleagues and close friends during the short period of their first contact was not inconsequential, for their relationship made possible Fröhlich's communication of his findings to Cushing, which would probably have remained unknown to him otherwise. Fröhlich's report of adiposogenital dystrophy would represent the essential information that persuaded Cushing that there was a link between the clinical symptoms he had observed in his own patient, caused by a congenital cyst lodged within the infundibulum, and the functional involvement of the pituitary gland..$^{1,2,50,65,68}$

\section{Diagnostic and Surgical Challenges Posed by Pituitary Case No. 3: Cushing's Troublesome Experiences With "Interpeduncular Cysts"}

With the limited resources that were available in the 1st decade of the 20th century, Cushing's decision to go ahead with the surgical removal of pituitary tumors, an entirely new field of surgery, represented, in the words of another renowned pioneer of pituitary surgery, Hermann Schloffer (1868-1937), "the mark of a daredevil venture." 66 This decision owes much to Cushing's adverse experience with Mary D. and her interpeduncular tumor. Fröhlich's report made a deep impression on Cushing. He immediately realized that Frölich's syndrome of adiposogenital dystrophy provided a reliable method of reaching an accurate clinical diagnosis of suprasellar tumors. Up to this time the presence of a pituitary tumor was basically inferred from the funduscopic examination, a well-established method of assessing the presence of papilledema or op- 
tic atrophy. ${ }^{56,79}$ Although plain skull radiographs, a technology introduced at Johns Hopkins by Cushing in 1896, allowed the confirmation of typical gross changes in the sella turcica caused by pituitary growths, Cushing himself could not take advantage of this technique to make the diagnosis of interpeduncular lesions like Pituitary Case No. 3 because such lesions usually developed above an intact sella turcica. Instead, he had the exceptional shrewdness to interpret the funduscopic finding of bilateral optic atrophy as the fundamental alteration produced by lesions developing in the interpeduncular area. ${ }^{33}$ The identification of optic atrophy and sexual infantilism in another patient he treated in 1905 motivated Cushing to report Mary D.'s case, despite his diagnostic and surgical failure..$^{33}$

A short time after Cushing reported his case of adiposogenital dystrophy in the young patient Mary D., he received reprints from Vienna of articles describing the first surgical procedures for removal of pituitary tumors using the transnasal-transsphenoidal approach. ${ }^{93}$ The young patient described by Fröhlich in his seminal 1901 paper on adiposogenital dystrophy was included among these early surgical experiences. In 1907, Fröhlich's 20 -year-old patient was worsening relentlessly, and he persuaded the surgeon Anton von Eiselsberg (1860-1939) to attempt a surgical exploration of the pituitary gland to confirm the presence of a large tumor in the region around the hypophysis. Von Eiselsberg eventually agreed and performed the procedure on June 21, 1907, draining the brownish, oillike fluid content of a large sellar-suprasellar cyst whose tissue characteristics corresponded unmistakably to those of a CP.11,17,39,79,92,93 The outcome of this procedure was outstandingly successful, for the patient remained alive in good condition for 15 years, up to his death in 1922. Alfred Fröhlich could not confirm this fact in 1939, at the first congress he attended in New York after being forced to leave Vienna and flee to America as a result of the Nazi annexation of Austria. ${ }^{17,42}$

In the spring of 1908, a young surgeon from Vienna who had assisted von Eiselsberg in the removal of the pituitary cyst from Fröhlich's patient visited Johns Hopkins and informed Cushing about the successful outcome in this case ${ }^{43}$ The fact that an effective surgical procedure had been performed in a case similar to his was particularly disturbing to anyone with Cushing's pride, and from that time on the pituitary gland and its tumors became the primary focus of much of his efforts ${ }^{43}$ From his early experience with Mary D. and her "interpeduncular cyst," Cushing understood that pituitary tumors could be classified into 2 major groups according to their topographical relationships: 1) tumors developing primarily within the gland, a group consisting of glandular hypertrophies or "strumas"; and 2) tumors developing primarily at a point away from the gland, mainly the group consisting of interpeduncular or "suprasellar cysts." "31 In an address delivered to the Congress of the American Medical Association held in Atlantic City in 1909, he remarked on the importance of reaching a precise topographical differentiation for tumors involving the infundibulum with these words: "I think it is important, in relation to tumors of the hypophysis, to distinguish between tumors arising from the hypophysis itself and tumors merely of the infundibular region." 53 It was not until 1914 that Cushing recognized the importance of visualization of suprasellar shadows on skull radiographs as a method of diagnosing interpeduncular cysts in patients with a normal sella. . $^{35,67}$

Throughout his career, Cushing struggled desperately to achieve an effective surgical method of dealing with the type of interpeduncular cyst he had observed for the first time in Mary D. Among the 43 surgically treated lesions described in The Pituitary Body and Its Disorders, 8 were infundibular/interpeduncular pituitary cysts (Table 1). ${ }^{31}$ Cushing remarked that most of the tumors within this subcategory arise from a congenital anlage (Erdheim's hypophyseal duct tumors), which can develop in the sphenoidal or infundibular regions. ${ }^{37}$ In June 1910 , Cushing introduced the use of a modified Halstead-Kanavel method for a transsphenoidal (TSF) approach to pituitary tumors, using a sublabial incision and submucosal resection of the septum (Fig. 6). . $^{31,51,60,62,79,86}$ Initially he alternated this approach with procedures of subtemporal decompression (Cases 4 and 16), but in 1911 and 1912 all cases, including interpeduncular cysts, were operated on through the TSF approach (interpeduncular cysts, Cases 6, 7, 17, 20, and 37) (Table 1). ${ }^{31}$ The TSF approach proved inadequate for
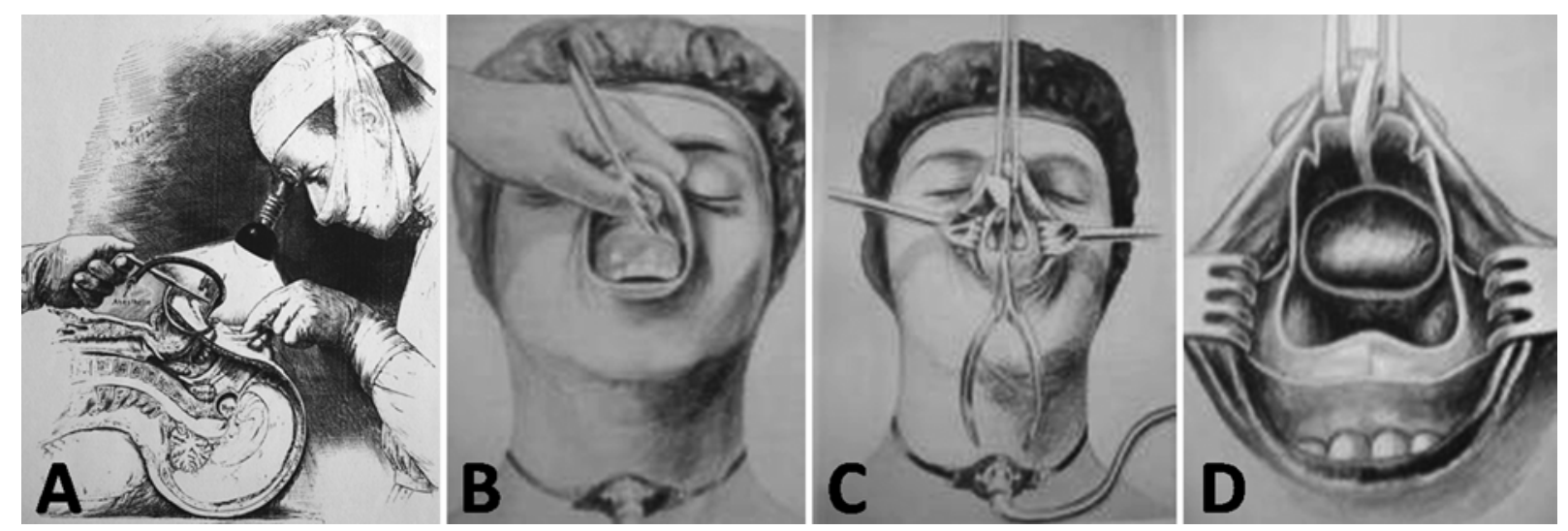

FIG. 6. A: Position used by Harvey Cushing from 1908 to 1929 for patients undergoing the sublabial transsphenoidal operation for removal of pituitary tumors and CPs. From Cushing: JAMA 63:1515-1525, 1914. B-D: Artist's renderings of the surgical stages of the sublabial transsphenoidal operation used for removal of a CP. From Halstead: Surg Gynecol Obstet 10:494-502, 1910. 


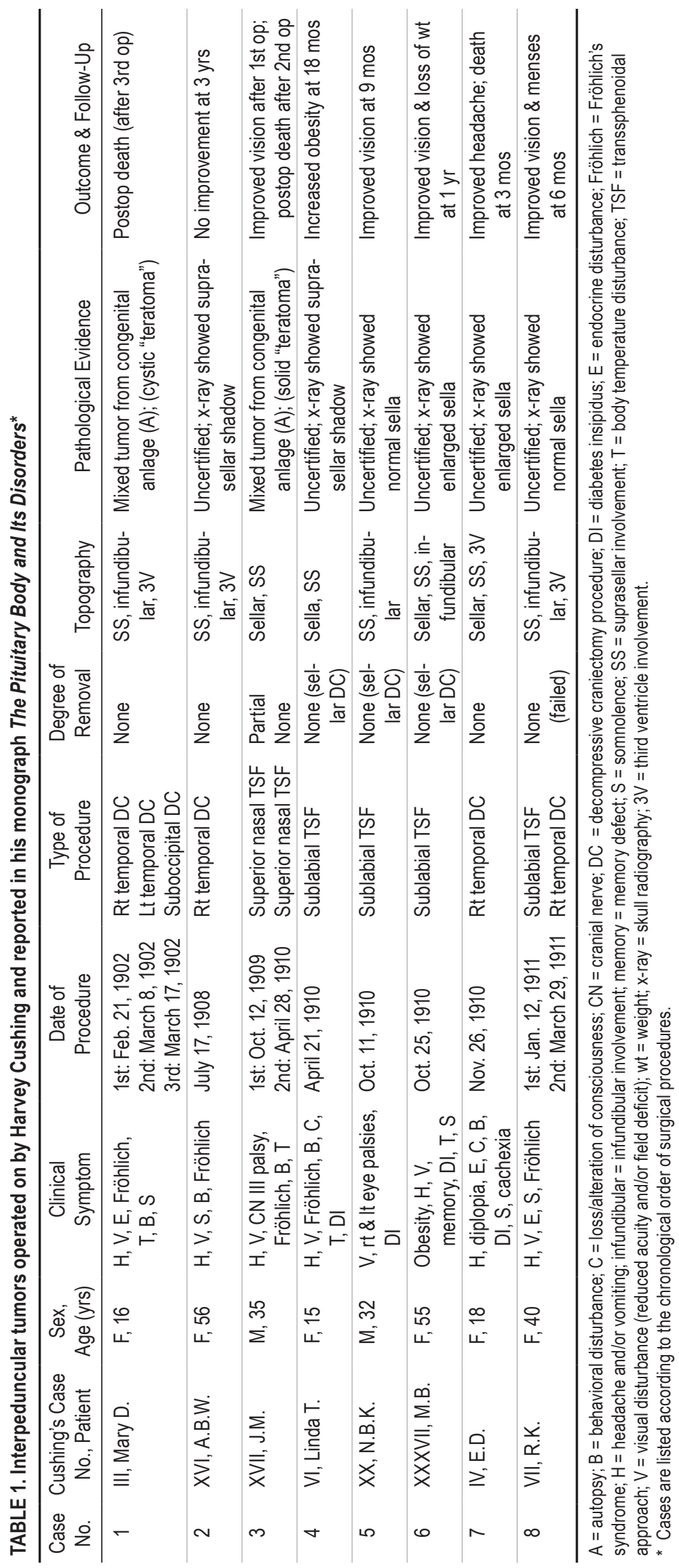


obtaining a proper exposure of purely interpeduncular tumors, and Cushing had to settle for a mere decompression of the sella turcica in most cases. Even so, this surgical method consistently alleviated symptoms of high intracranial pressure and temporarily improved visual disturbances in his patients. Nevertheless, the numerous failed TSF procedures performed in patients with interpeduncular (infundibulo-tuberal) CPs led Cushing to discontinue the TSF approach in favor of the subfrontal route, which he believed provided a better exposure of the chiasmatic region. ${ }^{21,25,29,30,76,77,79,86}$

\section{The Pathological Nature of Pituitary Tumor No. 3: A Teratoma or a Craniopharyngioma?}

What was the pathological nature of Mary D.'s interpeduncular cyst? Cushing and W. G. MacCallum carefully examined its gross macroscopic features and described it as a "golf ball-like" growth, formed by a smoothly rounded capsule of hard consistency owing to the presence of calcareous concretions. ${ }^{31,33}$ William H. Welch (1850-1934) defined the mass as a "teratoma," mainly because of his observation of a "mixed" tissue component with a presumed dual embryological origin (ectodermal and mesodermal). ${ }^{31,33}$ The most abundant component of the mass was epithelium of ectodermal origin, arranged in some areas as "glandular structures." He also observed areas of mesenchyme-derived tissues such as bone and embryonic hyaline cartilage. No hair, sebaceous glands, fat tissue, or muscle were observed in this tumor.

Although Mary D.'s interpeduncular tumor might have corresponded to a teratoma, abundant evidence strongly points to the fact that it actually corresponded to a $\mathrm{CP}$ of the adamantinomatous variant. At the time (1901) that Welch analyzed Mary D.'s infundibular lesion, the group of hypophyseal duct tumors had not yet been categorized. Neither Welch nor Cushing knew about Babinski's publication of a very similar epithelial infundibulum tumor showing a histological structure resembling that of adamantinoma of the jaw. ${ }^{4,26,33}$ Nomenclature for suprasellar and parasellar growths was extremely varied and confusing at that time. ${ }^{79,80}$ There are numerous examples in the literature of cystic and solid tumors of the infundibulum being diagnosed under a wide range of names including carcinoma, medullary sarcoma, and teratoma, when they

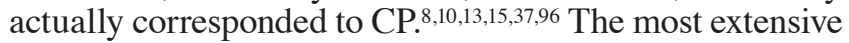
pathological classification of pituitary tumors, put forward by Boyce and Beadles in 1893, had classified most of these lesions simply with the term "infundibular cyst," a synonym for "suprasellar cyst" or "interpeduncular cyst," all of which were employed interchangeably in Cushing's pituitary monograph. ${ }^{15,79,80}$ It was the prominent Austrian pathologist Jacob Erdheim (1874-1937) who in 1904 finally classified the group of heterogeneous epithelial growths developing from the pituitary stalk or the infundibulum under the common category of "hypophyseal duct tumors" (Hypophysengangsgeschwülste) (Fig. 7). ${ }^{37}$ A misdiagnosis of teratoma was also frequently made, in particular for epithelial lesions including bone tissue, mature teeth, and epidermal adnexa such as hairs and sebaceous glands.

John Farquhar Fulton (1899-1960) reconsidered the nature of Mary D.'s interpeduncular tumor in his biography
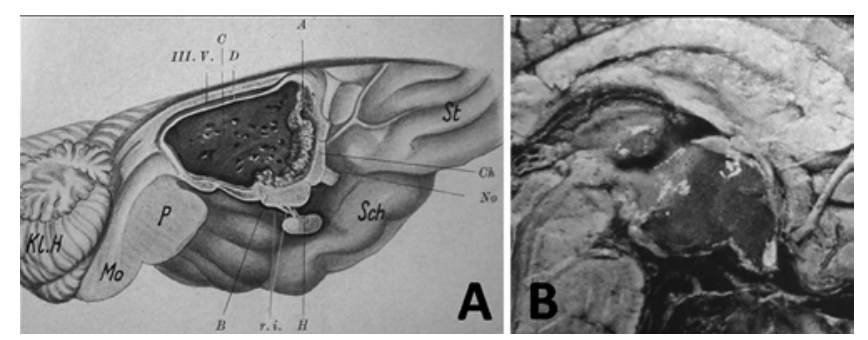

FIG. 7. Hypophyseal duct tumors or CPs developed at the third ventricle. A: Artist's illustration shows a midsagittal view of an infundibulotuberal CP diagnosed in a 16-year-old man who died after a 4-year-history of severe headache, progressive visual deficit, recurrent seizures, and obnubilation, followed by bradycardia and respiratory arrest. This "hypophyseal duct tumor" (a CP) confined to the third ventricle was described in Erdheim's original monograph categorizing this new group of infundibular tumors of congenital origin from remnants of Rathke's pouch. From Erdheim: Sitzungsb Kais Akad Wissen Math Naturw Klin 113:537-726, 1904. B: Sagittal image of a strictly intraventricular CP of the papillary type, a tumor almost identical to Erdheim's case. Cushing denominated this lesion initially as a "papillary infundibular cyst" in his monograph. From Cushing: The Pituitary Body and Its Disorders, JB Lippincott, 1912.

of Cushing, when he put the diagnosis of "teratoma" in quotation marks. ${ }^{43}$ Based on his extensive study of Cushing's personal documents, he argued that this lesion actually corresponded to "a tumor which we now know to have been a tumor that results from a developmental defect involving a structure to which the embryologist has given the name of Rathke's pouch" (Fulton 1946, p. 271). ${ }^{43}$ With these words Fulton asserts his belief that this lesion corresponded to a Rathke's pouch tumor or a CP. Sharing Fulton's opinion was Roy O. Greep, who asserted that both Fröhlich and Cushing's suprasellar tumors "are now known to be derived from the pharyngeal derivative of the anterior hypophyseal lobe or Rathke's pouch, the embryological anlage of the anterior pituitary" (Greep 1974, p. 3). ${ }^{50}$ It is worth mentioning that Cushing defines Case No. 3 in his monograph as "a tumor from a congenital anlage in the infundibular region," a definition typically ascribed to CPs. ${ }^{31}$ There is additional evidence supporting such an assumption. In the published account of the Harvey Society Lecture delivered by Cushing to the New York Academy of Medicine on January 19, 1933, on the subject of dyspituitarism, there is a footnote in which he recalled Mary D.'s case with the following words:

In December, 1902, there died in Dr. Osler's wards at the Johns Hopkins Hospital a sexually undeveloped girl of 16 with the symptoms described by Babinski, and whose case was subsequently reported in my first paper which in any way pertained to the pituitary body. ${ }^{26}$

Cushing again witnessed the report of a new "teratomatous" interpeduncular tumor in June 1909 at the 16th Annual Session of the American Medical Association held in Atlantic City. ${ }^{53}$ The lesion, found by Dr. D'Orsay Hecht and the pathologist Maximilian Herzog at the brain undersurface of an 11-year-old girl, consisted of a rounded epithelial tumor containing small calcareous particles and masses of hyaline material filling alveoli-like spaces (Fig. 8). The latter masses were described as

...not perfectly homogeneous, like typical colloid, but rather 


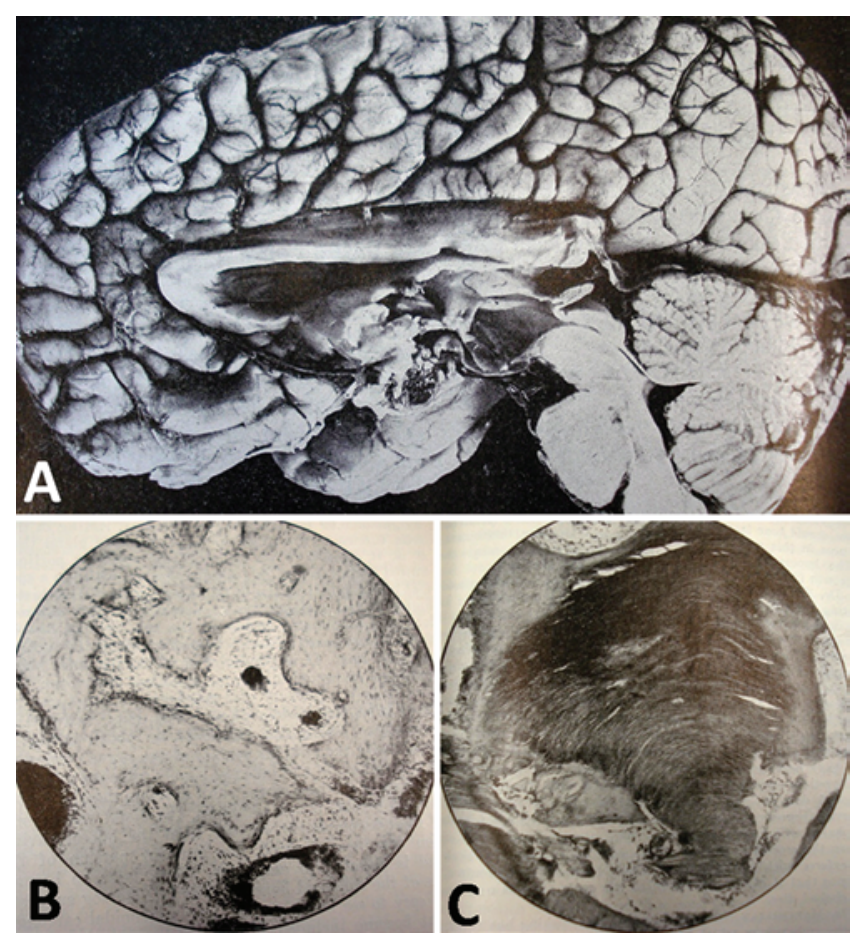

FIG. 8. Example of a "teratomatous" tumor of the infundibulum with histological features that closely resembled those of Mary D.'s interpeduncular lesion. A: Midsagittal brain view showing a solid-cystic infundibulotuberal tumor primarily developed at the tuber cinereum, which spared the pituitary stalk and pituitary gland and extended into the third ventricle. The tumor was considered a "teratoma" or "teratoid" (lesion containing tissues arising from 2 embryonic germinal layers, ectoderm and mesoderm), although it might well correspond to an adamantinomatous CP. B: Histological section of the lesion showing marrow spaces and lamellated bone (mesoderm-derived tissues). $\mathrm{H}$ \& E, original magnification $\times 100$. C: Histological section taken from an osseous portion of the tumor showing strongly calcified bone fibrils. $\mathrm{H} \& \mathrm{E}$, original magnification $\times 100$. From Hecht: JAMA 53:1001-1005, 1909.

scaly and [it] shows clearly its derivation from degenerating cells which have been molded together in the interior of the follicles but have not become completely fused. On the whole, these bodies in the interior of follicular spaces look somewhat like the epithelial pearls of cornifying carcinomata, although the material does not show any true cornification. It stains with Van Giesen from an almost pure yellow with some red, and even to deep reddish orange..$^{33}$

This description is typical of the pearls of "wet keratin" usually found in adamantinomatous $\mathrm{CPs}{ }^{88}$ The hard portions of the tumor consisted of osteoid tissue with a fibrillar structure (Fig. 8C). No cartilage was found in the tumor. In conclusion, this "mixed" type of tumor was classified as a teratoma because of the combination of tissues presumably derived, respectively, from the primitive ectodermal (epithelial tissue) and mesodermal layers (osteoid tissue) of the embryo. According to this description, it is very probable that Welch found a similar combination of epithelium arranged in alveoli, stellate reticulum, and osteoid tissue in the specimen he examined from Mary D.'s case. Areas of hyaline cartilage have been occasionally described in $\mathrm{CP}$ with metaplastic ossification and formation of osteoid and bone tissue. ${ }^{9,23,38,48,59,74}$ Alternatively, he could have easily misinterpreted masses of wet keratin in the tumor as foci of embryonal hyaline cartilage.

Observation of calcifications or ectopic bone in a suprasellar mass, two features frequently mentioned for the adamantinomatous variant of $\mathrm{CP}$, very often led pathologists in the first decades of the 20th century to erroneously classify the lesion within the category of a teratoma (Table 2). A late example of this "baffling" pathological diagnosis was reported in 1923 by J. H. Globus, who initially employed the term "teratoid" cyst of the infundibulum for a tumor identical to the lesions reported by Cushing and Hecht. ${ }^{45}$ Globus concluded that his cystic tumor, formed by a combination of ectodermal (squamous epithelium) and mesodermal (embryonal cartilage and bone) components, did not correspond to a true teratoma but to a "teratoid," which has a striking similarity to the cysts derived from the hypophyseal duct described by Erdheim. ${ }^{37}$ Eventually, Globus reclassified his lesion as a CP. ${ }^{46}$ This differentiation, among parahypophyseal lesions, between true teratomas (tumors containing tissues derived from the 3 germinal layers) and "teratoids" (tumors containing tissues derived from only 2 germinal layers) is supported by other authors such as the pioneering pediatric neurosurgeon Franc D. Ingraham (1898-1965) and the German neuropathologist Klaus Zülch (1910-1988). ${ }^{58,100}$

In the discussion of Dr. Hecht's "teratoma" case, Maximilian Herzog remarked that the "mixed" ectodermal-mesodermal type of tumor usually found in the infundibular area does not correspond to the type of teratomata that may contain all kind of body tissues, as seen for example in tumors arising from the germ cells of ovary or testis, but rather to the type of developing structures from a limited embryonic region, in this case the primitive mouth [authors' paraphrase]. ${ }^{53}$ Epithelial and glandular structures derived from the primitive stomodeum, including dental germs and bone tissue, can be found in lesions at this level. These histological structures can be present within the overlapping spectrum of epithelial tumors developing along the Rathke's pouch pathway of migration, from epidermoids and dermoids to Rathke's cleft cysts and CPs. ${ }^{52,83,99}$ Some cases of suprasellar lesions diagnosed as teratomas in actuality corresponded to odontogenic or toothy CPs containing mature teeth or structures derived from the dental germs. ${ }^{8,18,63}$ The epithelial cells rostral to the oral plate proliferate during embryonic life at the same time as dental germ formation, a fact that supports the embryological origin of CPs from tissues of the primitive stomodeum, among them the dental ridge and tooth primordia. ${ }^{48,61,90}$

In his late 1932 monograph on intracranial tumors, Cushing included the categories of CPs and teratomas within the chapter devoted to congenital intracranial tumors. ${ }^{30}$ Only 4 teratomas are mentioned in this chapter. Notably, as direct evidence of the actual CP nature of Pituitary Case No. 3, Cushing openly expresses his doubts about the actual pathological nature of the 2 suprasellar lesions diagnosed as "teratomas," doubts previously manifested in his handwritten notes in the reprint of the 1906 article. ${ }^{43} \mathrm{He}$ differentiates between the 2 "obscure" teratomas with a parahypophyseal topography and the remaining 2 lesions (a pineal growth of a true germinal nature 


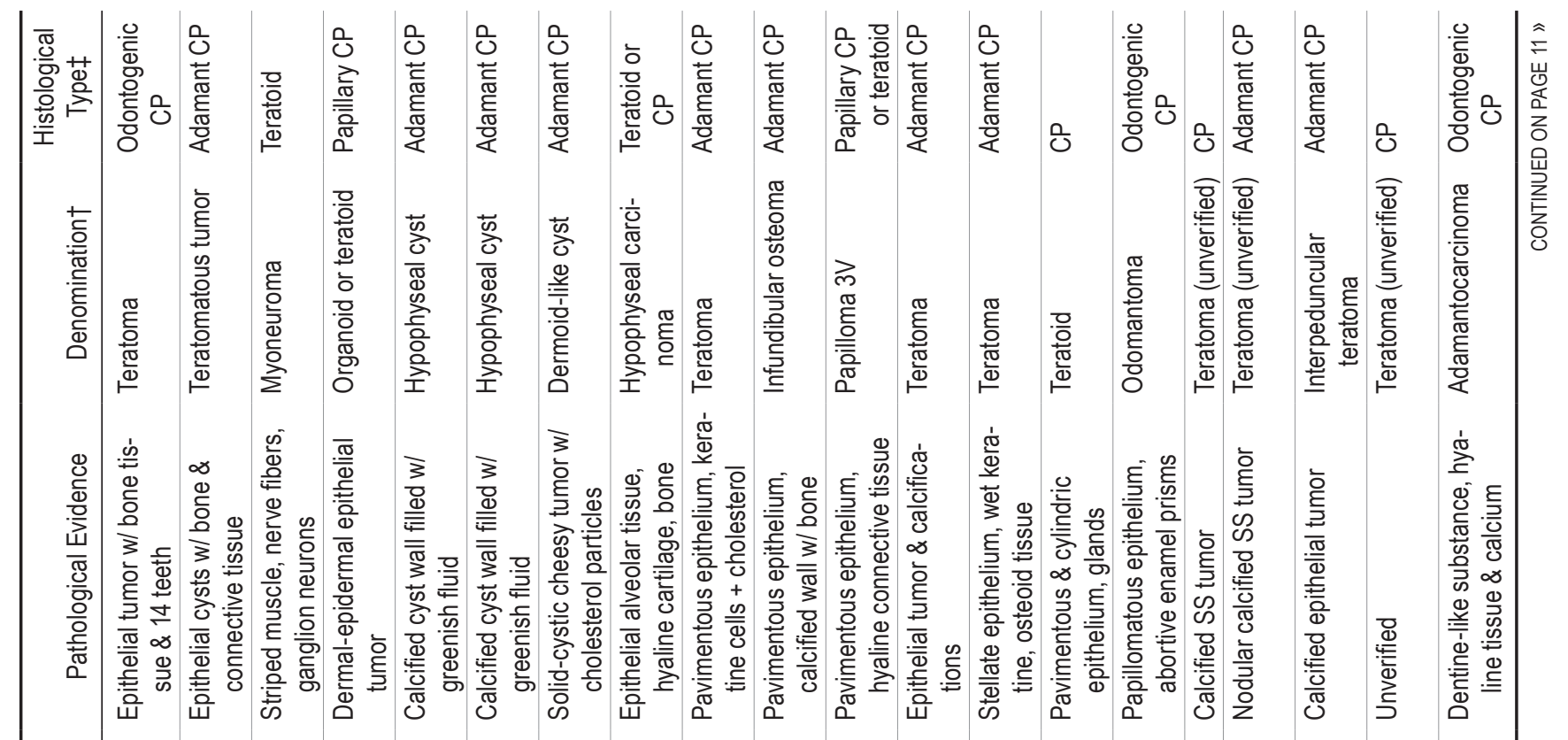

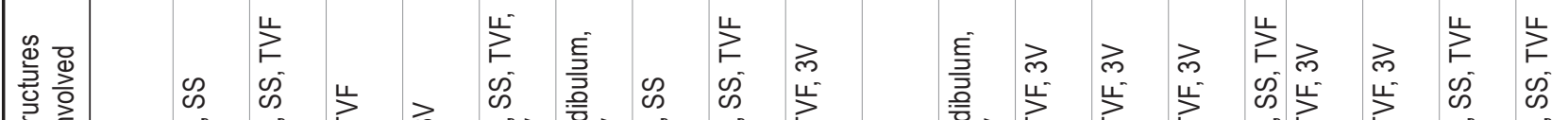

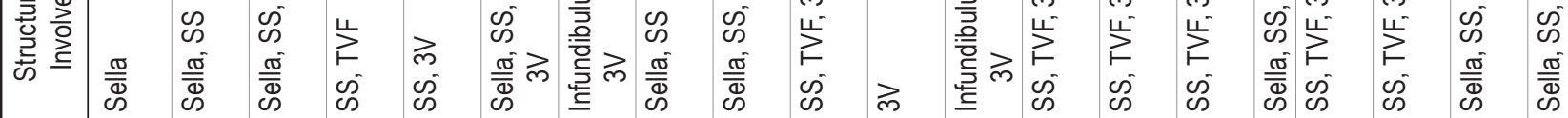

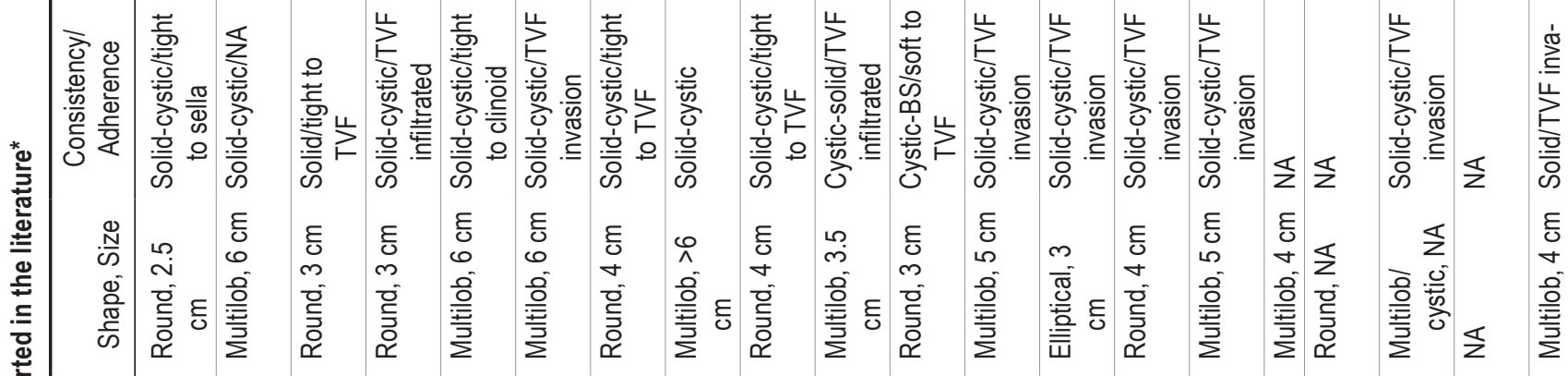

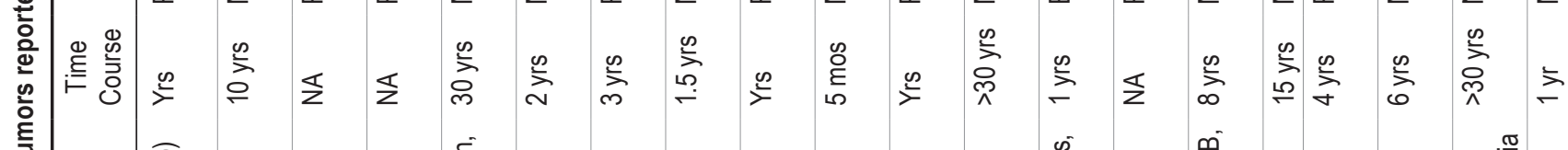

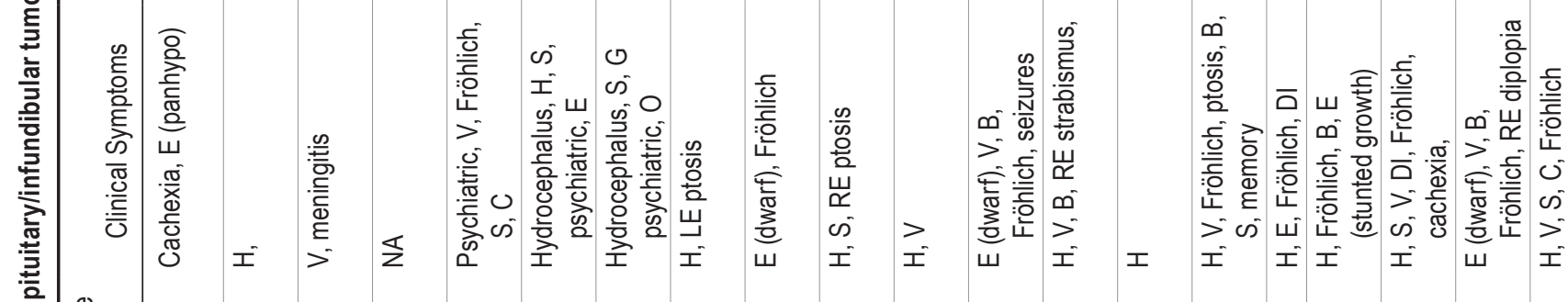

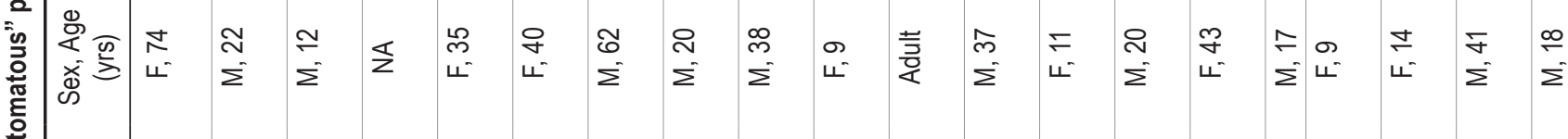

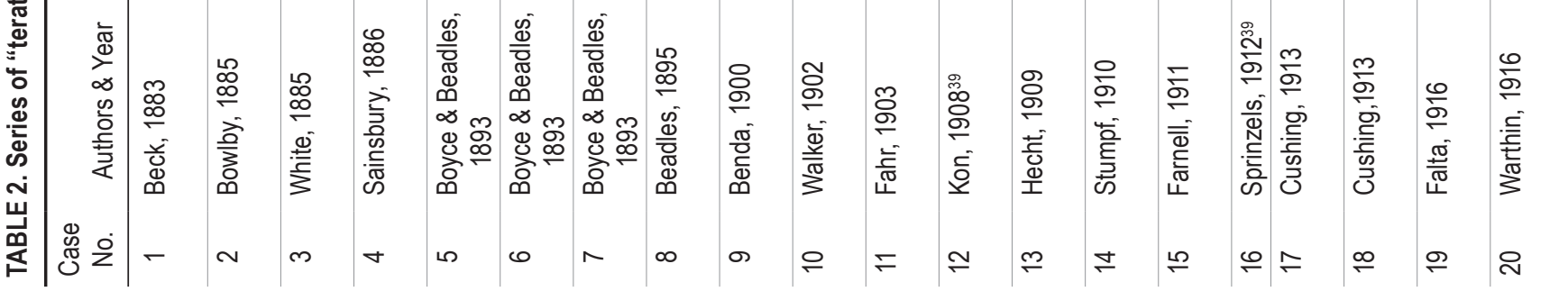




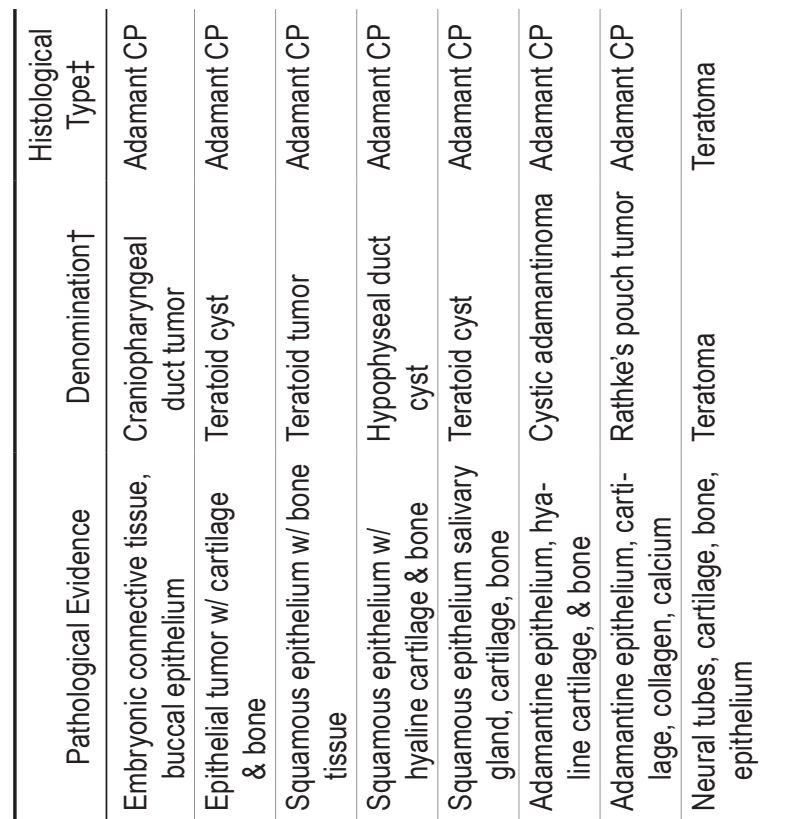

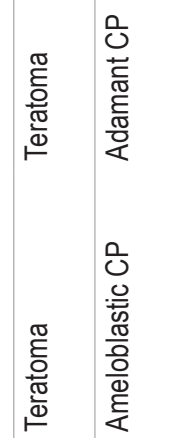

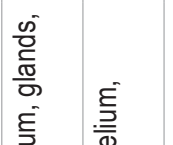

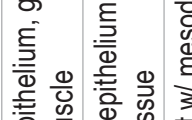

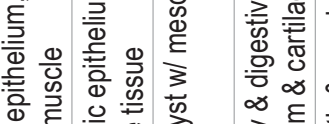

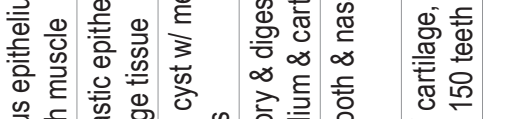

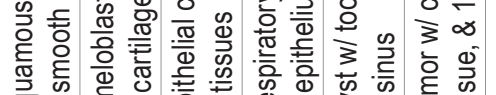

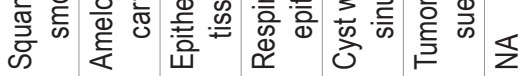

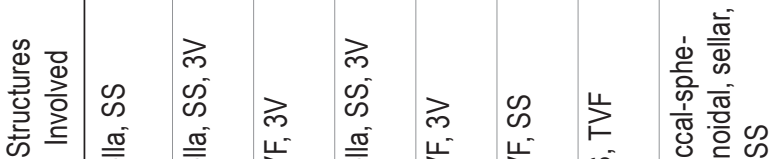

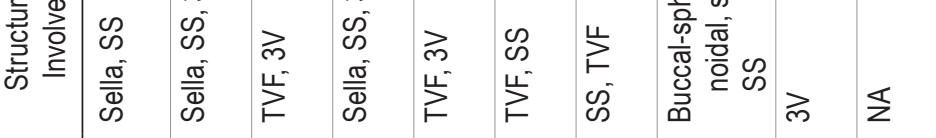

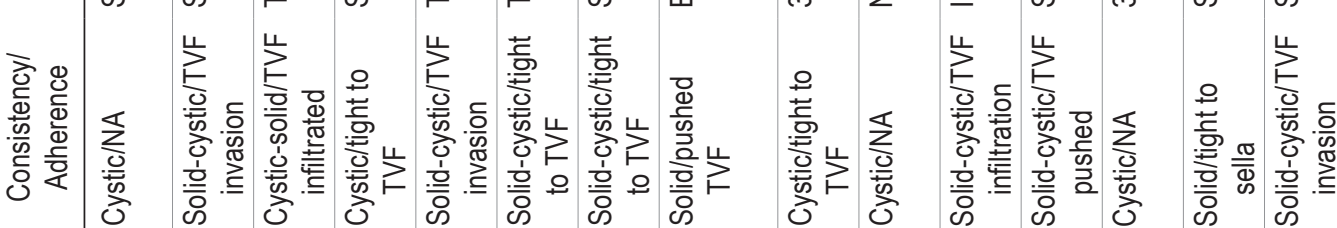

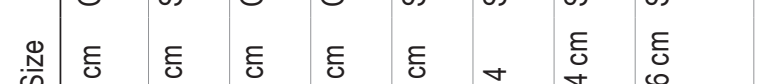

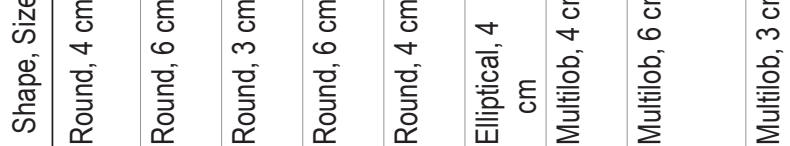

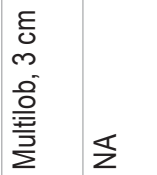

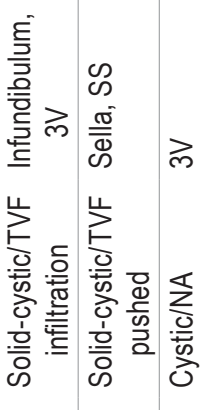

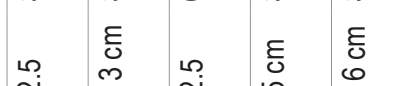

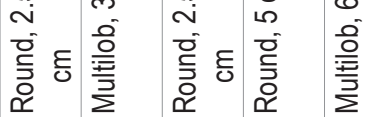

흥

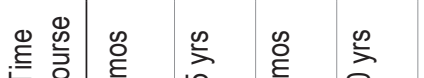

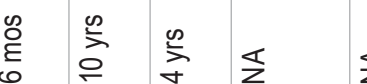

总

is

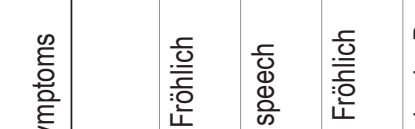

일

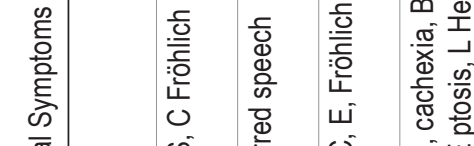

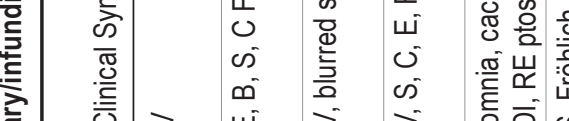

蒙

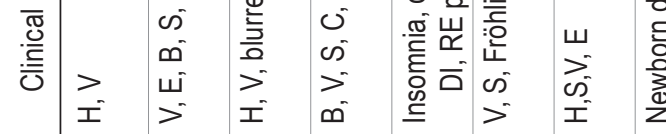

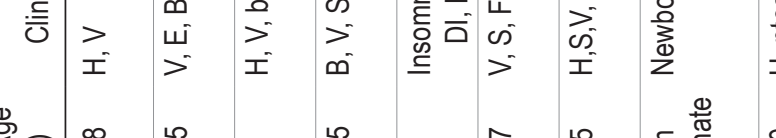

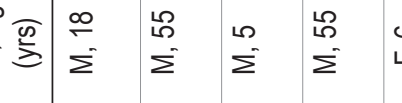

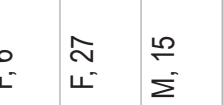

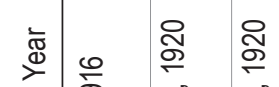

㟧

(1)

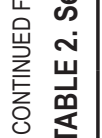

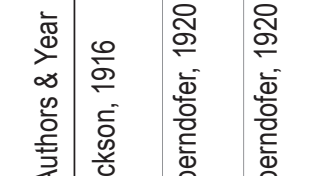

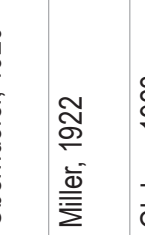

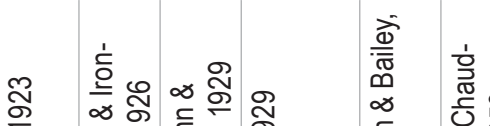

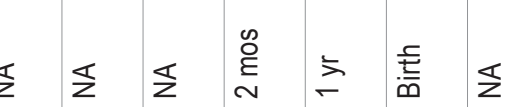

$\frac{\sqrt{\frac{0}{2}}}{\frac{0}{\frac{0}{0}}}$

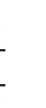
( 
and a huge congenital tumor occupying the whole cranial cavity in a newborn). ${ }^{29}$ One of these "obscure" teratomas showing a suprasellar or interpeduncular position was precisely Mary D.'s case. The second example corresponds to Pituitary Case No. 17 (XVII in the original) in Cushing's monograph, a lesion Dr. Welch again judged a "mixed tumor from a congenital anlage" (teratoma), based on his observation of myxomatous epithelium and connective tissue containing embryonic cartilage and a few bone cells (Table 1). Actually, the tumor corresponded to a parasellar chordoma, as shown in the files of the Cushing Brain Tumor Registry [Fig. 81, p. 523]. ${ }^{22}$ This mistaken diagnosis evidences early difficulties in establishing the accurate histological diagnosis of "mixed interpeduncular lesions," especially the differentiation of true teratomas from other entities such as Rathke's pouch tumors (CPs), cholesteatomas, and chordomas. Cushing did not provide information about the 2 parahypophyseal teratomas in his 1932 monograph, probably because he sensed that the histological diagnosis was inaccurate in both cases.

\section{Contribution of the "Lost Pituitary Teratoma" to the Birth of Neurosurgical Pathology: The Genesis of the Harvey Cushing Brain Tumor Registry}

The true "teratomatous" nature of Mary D.'s interpeduncular tumor could never be verified. Cushing regularly examined all tissues removed during surgical procedures, a habit he acquired from Halsted. He had even drawn a beautiful illustrative sketch of the patient's brain undersurface showing the position and macroscopic aspect of the tumor (reproduced in Fig. 5), an illustration included in the 1906 report of the case as well as in his 1912 pituitary monograph..$^{30,33}$ At the bottom of the original illustration a hand-written annotation by Cushing says, "Drawing, of base of brain and tumor (Case I) from sketch of the tissues made at the time of the autopsy," a legend in which the author remarks that this autopsy corresponds to the very first intracranial tumor case he had operated on at Johns Hopkins. ${ }^{22}$ Despite Welch's original description of this mass as a "teratoma," Cushing requested from the Pathological Department an additional histological verification, probably within a short time after studying the reprint of Fröhlich's report on his own pituitary case. Fulton highlights in his Cushing biography how the young surgeon had to contain his fury when the staff of the Johns Hopkins pathology department informed him that the tissue specimen had been misplaced. Such careless handling or storing of pathological specimens was not acceptable to Cushing. ${ }^{43,94}$ His firm resolution was to demand from Johns Hopkins managers that, from that day on, he should be allowed to keep all records of clinical charts as well as all specimens removed from his operative procedures or from autopsies performed on his patients..$^{22,43,94,95}$ After some deliberation, William Welch and W. G. MacCallum agreed to Cushing's demands, and this concession sowed the seed for the genesis of the Harvey Cushing Brain Tumor Registry.

Cushing meticulously recorded and documented each patient story, an obsessive practice he carried through his entire career as a neurosurgeon. Cushing himself sec- tioned the gross specimens for study, dictated the macroscopic pathological findings, and provided a double set of tissues for histological analysis to both the Department of Pathology and his own laboratory. ${ }^{22}$ In this endeavor, he received the indispensable assistance of 2 neuropathologists, Percival Bailey and Louise Eisenhardt. Bailey worked as an appointee to the surgical laboratory of Peter Brent Brigham Hospital between 1920 and 1928 while completing his trainee period as neurosurgeon at the same time. Louise Eisenhardt replaced Bailey for the last period of Cushing's career, from 1929 to 1932 (and then collaborated with him in his academic work and the organization of the Brain Tumor Registry). Bailey and Eisenhardt both acted as expert neuropathologists who performed the autopsies, analyzed the gross anatomical and histological specimens, and issued the diagnosis, at the same time that the "official" pathologists at the Peter Bent Brigham laboratory delivered their own judgments. With this "doublecheck" Cushing made sure that the nature of the lesion was accurately addressed and kept his own set of samples and specimens for future research, which allowed the development of new pathological classification schemes. It was Cushing's personal aspiration that his huge collection of photographs, clinical notes, surgical operative sketches, and tissue specimens become a database of clinical information in the founding stages of modern brain surgery, to be used in future research projects. Cushing's painstaking methods, which gave rise to his astounding collection and, ultimately, to the creation of his Brain Tumor Registry, exemplify an ideal construct for clinical research. The formal organization of Cushing's collection, however, did not occur until after 1932, when he retired from his position as Moseley Professor of Surgery at Boston's Peter Bent Brigham Hospital. At that time, he hoped his collection would stay in Boston to become a formal repository for brain tumor specimens of all sorts, a dream that would never be realized. Unforeseen circumstances forced Cushing to move his collection to Yale. Although Welch and MacCallum maintained enthusiasm about Cushing's "private" collection, Dr. S. Burt Wolbach, chief of the department of pathology at Peter Bent Brigham, was not so appreciative. $^{22,43}$ The necessary funds to refurbish the Warren Museum, a possible location at Harvard's Department of Pathology to house the registry, were never granted. When Cushing accepted a position at the Yale Medical School as Sterling Professor of Neurology, he finally arranged to have the entire Registry brought with him, including microfilmed copies of patient records. ${ }^{43,94}$

Mary D.'s "infamously lost" tissue specimen from Pituitary Case No. 3 of 1902 was the definitive catalyst that would lead to the creation of the Harvey Cushing Brain Tumor Registry, as it is known today. The Registry constitutes an immense archival collection of over 2200 neurosurgical case studies, including whole human whole brain specimens, intracranial tumor specimens, microscopic slides, notes, and more than 15,000 photographic negatives of patients and their clinical findings, gathered by Harvey Cushing throughout his career. ${ }^{22,94,95}$ Currently housed at Yale University, it represents a scientific and historical archive of inestimable value that chronicles the birth and evolution of modern neurosurgery as a scientific discipline 
in Cushing's own hand. This archive, embodying the tireless obsession for documenting and recording clinical and surgical activity, probably comprises Cushing's most significant and long-lasting legacy to neurosurgery.

\section{Cushing's Pituitary Case No. 3: A Type of Lesion Evidencing the Separation of Hypothalamic and Hypophyseal Functions}

Mary D. and the other patients with interpeduncular cysts described in Cushing's monograph all showed some peculiar symptoms typically associated with a gross distortion of the infundibulum and the adjacent region of the hypothalamus. ${ }^{31}$ Among these, the most remarkable symptoms include adiposogenital dystrophy (Fröhlich's syndrome), marked drowsiness, apathy, fits of rage with hyperphagia, demented behavior, and abnormal changes in body temperature ${ }^{20}$ Harvey Cushing was well aware of these symptoms, which he initially attributed to a "polyglandular" disturbance associated with hypophyseal insufficiency. Cushing considered the pituitary gland, not the infundibulum or the "tuberal centers" of the hypothalamus, to be the origin of Fröhlich's syndrome. His opinion resulted from his long experimental research on hypophysectomy in dogs, through which he had achieved the reproduction of a Fröhlich syndrome-like phenotype (Fig. 9). ${ }^{24,47}$ In 1907, the Romanian physiologist Nicolae C. Paulescu (1869-1931) had employed a transtemporal technique for removal of the canine pituitary and concluded that the pituitary gland was essential for life. ${ }^{82}$ After assessing another patient with symptoms typical of Fröhlich syndrome (Case Daisy W.), whose case was published in 1906 together with that of Mary D., Cushing decided to repeat Paulescu's experiments at the Hunterian Laboratory (Fig. 10) with the assistance of his colleague Lewis L. Reford. Hypophysectomized dogs developed a peculiar group of symptoms such as arched-back tonic posture, head drooping, apathy, low body temperature, and progressive emaciation that progressed to coma and death within a few days (Fig. 11). Cushing grouped these symptoms under the term "cachexia hypophyseopriva" and concluded, in agreement with Paulescu's results, and contrary to Victor Horsley's opinion, that "total hypophysectomy is incompatible with the maintenance of life." 55,85

From time to time, however, animals did not die following pituitary removal; they merely got fat (see Fig. 9). Cushing set up a new series of experiments, and in 19081909 he put 2 of his assistants, Samuel J. Crowe and John Homans, to work intensively on the operative removal of canine pituitaries. ${ }^{43}$ The results of the large series of 100 hypophysectomized dogs were published in 1910 and provided Cushing with the experimental basis for a new conceptualization of the clinical symptoms derived from hypophyseal insufficiency, the notion of hypopituitarism..$^{24,29}$ Years later John Homans related to John Fulton how the work on experimental hypophysectomy had allowed Cushing to establish the relationship between Fröhlich's syndrome observed in Mary D. and other patients with interpeduncular tumors and a state of hypophyseal insufficiency:43

When I arrived in Baltimore, in the autumn of 1908, Cushing

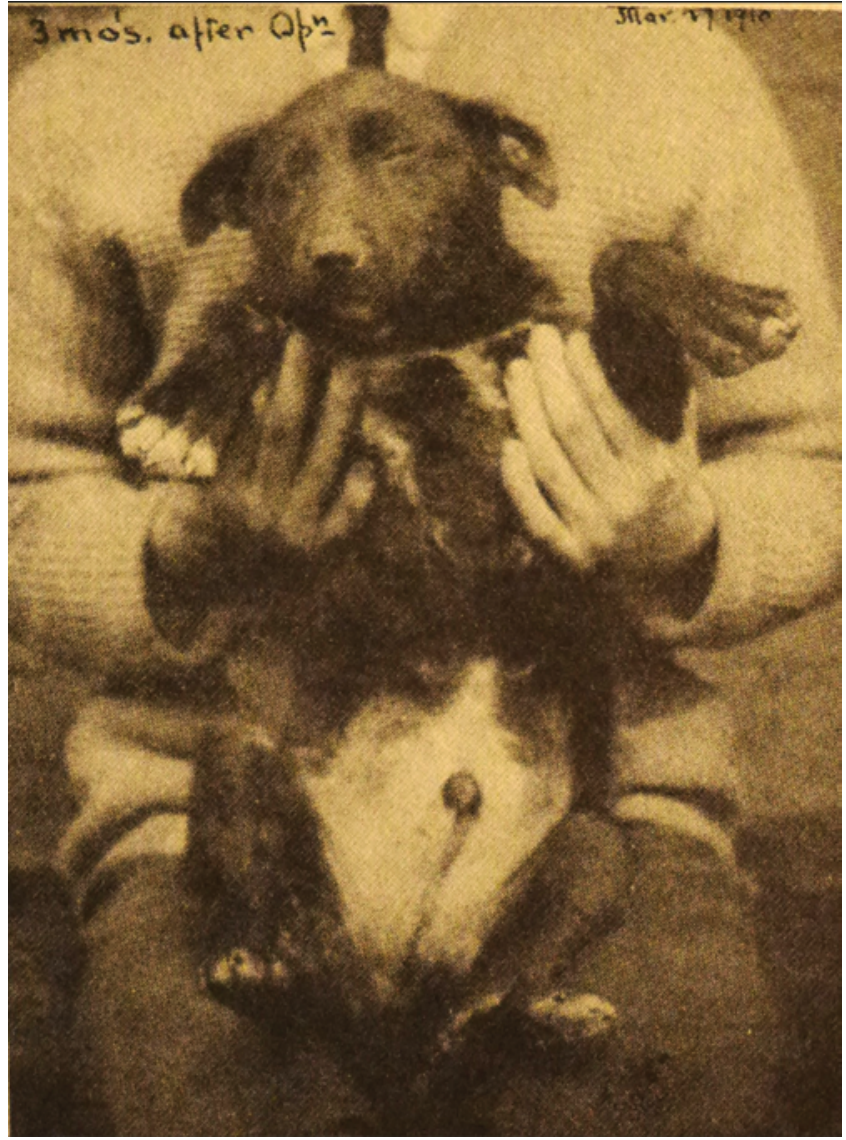

FIG. 9. Fröhlich-like phenotype developed in a 6-month-old puppy, 3 months after experimental hypophysectomy. Notice how the animal became dull, fat, undersized, and sexually infantile. From Cushing: The Pituitary Body and Its Disorders, JB Lippincott, 1912.

had decided to interest himself particularly in the hypophysis. He set Crowe and the rest of us to making hypophysectomized animals. It soon appeared that, though many of these died within a few days in a state of what was called cachexia hypophysiopriva, some animals survived for many months. These animals were carefully looked after but, on the whole, were passed for the time being as freaks in which something had marred the completeness of hypophysectomy. Finally, I remember that one of these animals died; it was an extraordinarily fat, loggy, sexless creature. One day Cushing caught sight of another of these animals while it was still alive, I'm quite certain, and said at once: "Here is Fröhlich's asexual adiposity." From the fact that the animal was nearly or perhaps entirely without hypophysis, he judged this represented a state due to hypophyseal deficiency, as opposed to acromegaly which must represent an overfunction of the gland. This latter condition was beginning to be recognized as such, but the sexual adiposity had been very confusing, because this seemed to be due to an enlargement of the hypophysis. ${ }^{43}$ (p. 281)

According to Homans, it was Cushing's quickness and insight in linking the hypophyseal adiposity in dogs with the Fröhlich's syndrome he had observed in patients such as Mary D. that allowed him to establish the concept of hypopituitarism. ${ }^{43}$ Cushing's long-lasting hypothesis was that the posterior lobe of the hypophysis was involved in the control of metabolic processes in tissues, its insufficiency causing a markedly accelerated accumulation of 

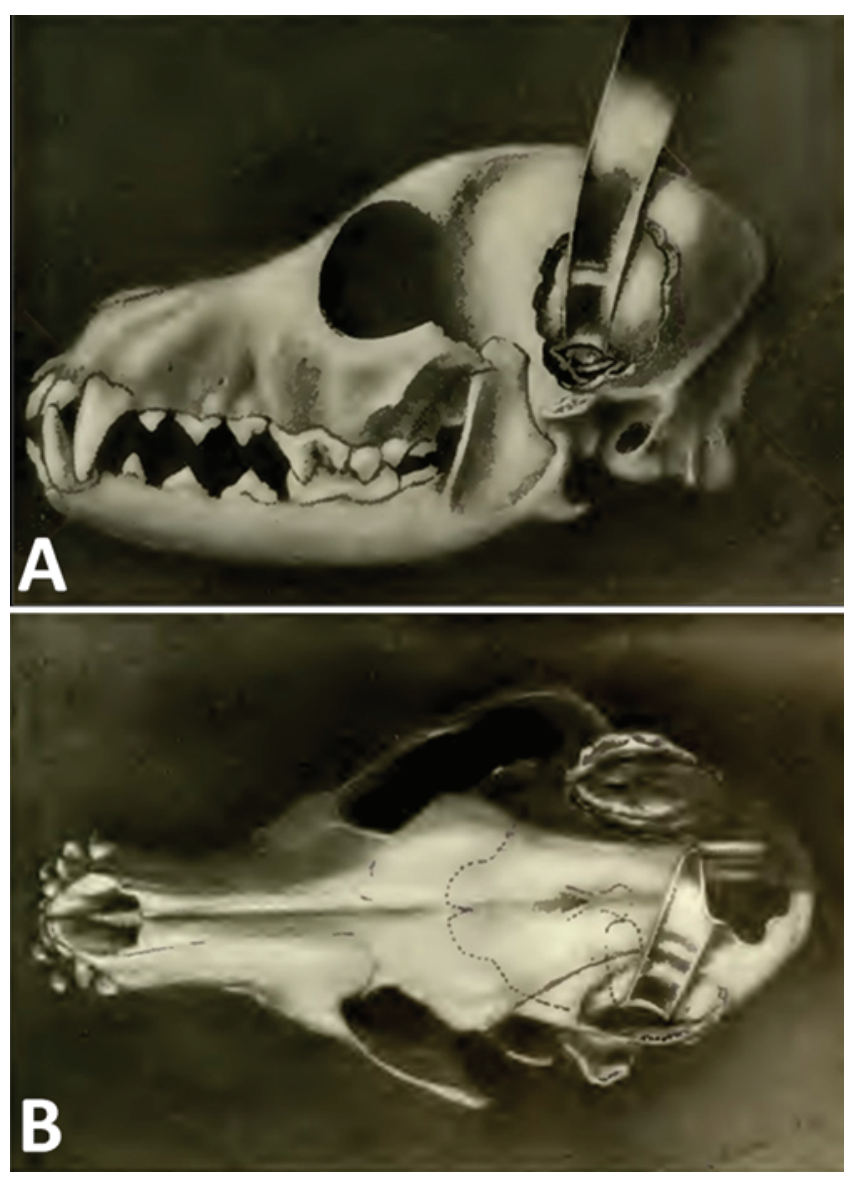

FIG. 10. Surgical procedure for subtemporal approach in dogs employed by Cushing's team to perform experimental hypophysectomy at the Hunterian Laboratory. Drawings show the lateral defect and cranial landmarks of the pituitary gland in the left lateral subtemporal approach. A: Lateral view: tip of curved spatula entering between internal carotid and third cranial nerve with gland visible. B: Superior view: curved spatula in place, elevating temporal lobe. Note outward displacement of right cerebral hemisphere through defect in bone and dura. From Crowe: Johns Hopkins Hosp Bull 21:127-169, 1910. fat, in addition to diabetes insipidus. ${ }^{47}$ The clinical classification of pituitary functional states proposed in Cushing's 1912 monograph made him the leader in the field and contributed to worldwide acceptance of his interpretation of Fröhlich syndrome as a primary hypophyseal disturbance. ${ }^{31}$ Nevertheless, multiple sources pointed to the alternative hypothesis of a primary dysfunction of the hypothalamus in the genesis of adiposogenital dystrophy.

Cushing's theory was based on mistaken interpretations of the physiological role played by the posterior lobe of the hypophysis. In 1908, the physiologist P. T. Herring proposed that the "hyaline bodies" he had observed within the posterior lobe of feline pituitary specimens corresponded to the hypertensive and diuretic pituitary substance identified by W. H. Howell in 1898.54,57,72 These researchers, as well as Cushing, believed it inconceivable that the neuroglia and nerve fibers that made up the posterior lobe could have any secretory function. Consequently, they assumed that the hyaline substance in the posterior lobe was secreted by the pars intermedia. The experiments of pituitary stalk sectioning performed by Crowe, Cushing, and Homans at the Hunterian Laboratory also displayed an accumulation of colloid or hyaline material along the pars nervosa of the pituitary gland, supporting Herring's interpretation (Fig. $12 \mathrm{~A}$ and B). ${ }^{24}$ Cushing's explanation for "Herring's hyaline bodies" assumed the existence of an ascending hormonal secretion pathway from the anterior lobe of the gland through the posterior lobe and then through the neurohypophyseal stalk toward the CSF in the infundibulum (Fig. 12C). His theory matched well with the appearance of Fröhlich's syndrome in Mary D. and other patients with infundibular tumors (congenital Rathke's pouch cyst or CPs). As the pituitary gland was usually observed intact below these tumors, Cushing speculated that mechanical obstruction to upward release of pituitary secretions into the third ventricle was the cause of Fröhlich's syndrome observed in these patients. ${ }^{24,29}$

Cushing's doctrine, however, was not universally accepted, as increasing evidence from pathological observations and well-designed experiments of lesions to the infundibulum and tuber cinereum went against his claims. ${ }^{1,2,65,68}$ Interestingly, the British neurologist Sir Byrom Bramwell (1847-1931) had already recorded the asso-
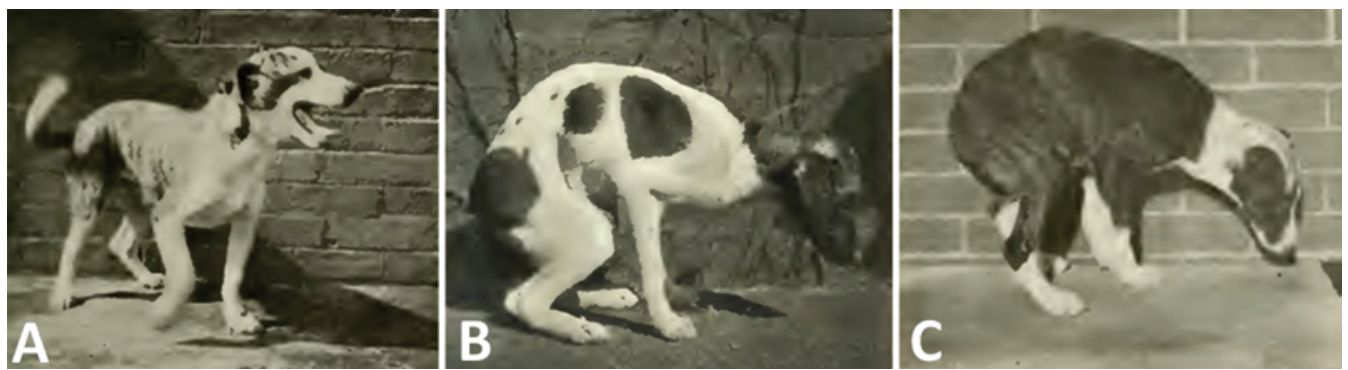

FIG. 11. Symptoms of cachexia hypophyseopriva in dogs after surgical removal of the pituitary gland. A: Photograph of a dog 5 months after removal of the posterior lobe of the pituitary gland. Note the animal appears very lively and playful (difficult to photograph). There are no appreciable symptoms consequent upon operation, with possible exception of erotomania. B: Observation 60: Fox terrier puppy, 14 days after total removal. Photograph taken a few hours before death. Temperature $22^{\circ} \mathrm{C}$, respiration 6 per minute. Note the typical attitude with arched back, characteristic of onset of cachexia hypophyseopriva. C: Observation 83: 1 month after stalk separation. Observe a similar characteristic attitude to that of cachexia hypophyseopriva, with incurvation of tail and humping of back. From Crowe: Johns Hopkins Hosp Bull 21:127-169, 1910. 

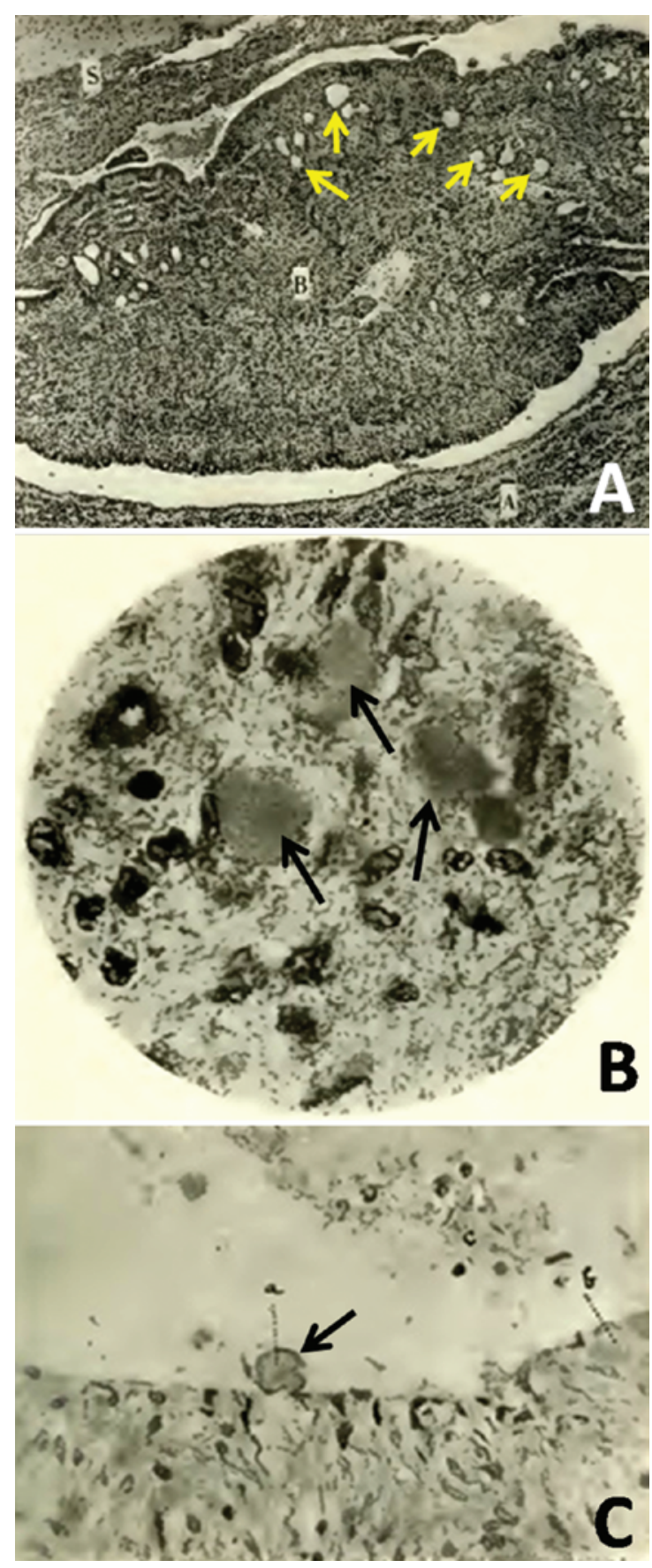

FIG. 12. Histological effects of experimental hypophysectomy supporting Cushing's theory of an "ascending hormonal secretion pathway" from the anterior glandular lobe through the neurohypophyseal stalk toward the infundibulum and third ventricle. A: Histological section of the pars nervosa after stalk separation. Drops of hyaline substance and small cysts containing a colloid substance are observed at the dorsal border of the posterior lobe (yellow arrows). Anterior lobe remains normal. Cushing interpreted this finding as the result of a dam-like effect caused by sectioning of the stalk, with retrograde accumulation of ascending pituitary secretions. B: Hyaline drops observed within the pars nervosa at higher magnification (black arrows). C: Hyaline bodies observed at the level of the floor of the infundibulum, "before" discharge (b) and "after" discharge (a, black arrow). Cushing acknowledged that this picture is not a common finding, and the drop of hyaline substance labeled "a" might well correspond to an artifact. From Crowe: Johns Hopkins Hosp Bull 21:127-169, 1910. ciation of obesity with gross distortion of the diencephalon by large pituitary tumors in $1888 .^{16}$ Bramwell's observations were confirmed in 1904 by the Austrian pathologist Jakob Erdheim (1879-1937), whose detailed pathological studies on necropsy specimens of hypophyseal duct tumors (CPs) led him to conclude that the obesity present in patients with lesions developing in the infundibulotuberal area were not related to damage to the pituitary gland but, rather, to an injury to unknown centers of the third ventricle floor. ${ }^{37}$ After learning of Erdheim's assertion, the Viennese physiologist Bernhard Aschner (1883-1960) challenged Cushing's interpretation by performing pituitary removal in dogs using a new transpalatal technique to cut the gland off from the infundibular stalk without damaging the hypothalamus (Fig. 13A and B). ${ }^{3}$ His painstaking research doubtlessly showed that isolated hypophysectomy stunted the growth of the dogs but that these animals did not become obese (Fig. 13C). He refuted Cushing's theory by suggesting that obesity in Cushing's dogs might be due to contusions in the base of the brain produced during surgical manipulation of the pituitary gland (Fig. 14).,24 Nevertheless, Aschner's and Erdheim's contentions were silenced, as nobody ventured to challenge Cushing's views after publication of his monograph.

Ironically, it was one of Cushing's most talented assistants, Percival Bailey (1892-1973), who, in 1921, proved conclusively, with the help of Frederic Bremer, that Fröhlich's syndrome could be induced by lesions strictly limited to the hypothalamus without injury to the pituitary gland. ${ }^{6}$ Essentially the same results had been reported in 1913 by the French physiologists Jean Camus (1872-1924) and Gustave Roussy (1874-1948). ${ }^{19}$ The preeminent role of the hypothalamus in the adiposogenital syndrome was summarized by Bailey and Bremer in the conclusion of their work: "We have given proof that it is possible to provoke cachexia hypophyseopriva and the adiposogenital syndrome (together with a permanent DI [diabetes insipidus]) by puncture of the postinfundibular region of the hypothalamus without touching the pituitary..."6 Bailey's results were taken grudgingly by Cushing, but after a decade of fruitless struggle he finally had to accept the new "hypothalamic" doctrine. ${ }^{30}$

\section{Abnormal Sleepiness and Behavior: Clinical Landmarks of Hypothalamic Dysfunction in Mary D.'s Infundibular Tumor}

Most tumors displayed in Cushing's monograph The Pituitary Body and Its Disorders encroached on the hypothalamus or invaded the infundibulotuberal area of the third ventricle floor (Fig. 15B). ${ }^{31}$ In fact, the group of interpeduncular or suprasellar cysts described in the book, including Mary D.'s case, correspond to lesions developed primarily at the infundibulum and tuber cinereum (Table 1) ${ }^{75-81}$ Although neither the word "hypothalamus" nor the term "tuber cinereum" is mentioned in the text, Evelyn Anderson rightly points out that Cushing's monograph might well be entitled "The Pituitary and Hypothalamus and Their Disorders," for it contains a remarkable collection of case histories involving hypothalamic disorders. ${ }^{1}$ Some of these distinctive hypothalamic symptoms asso- 

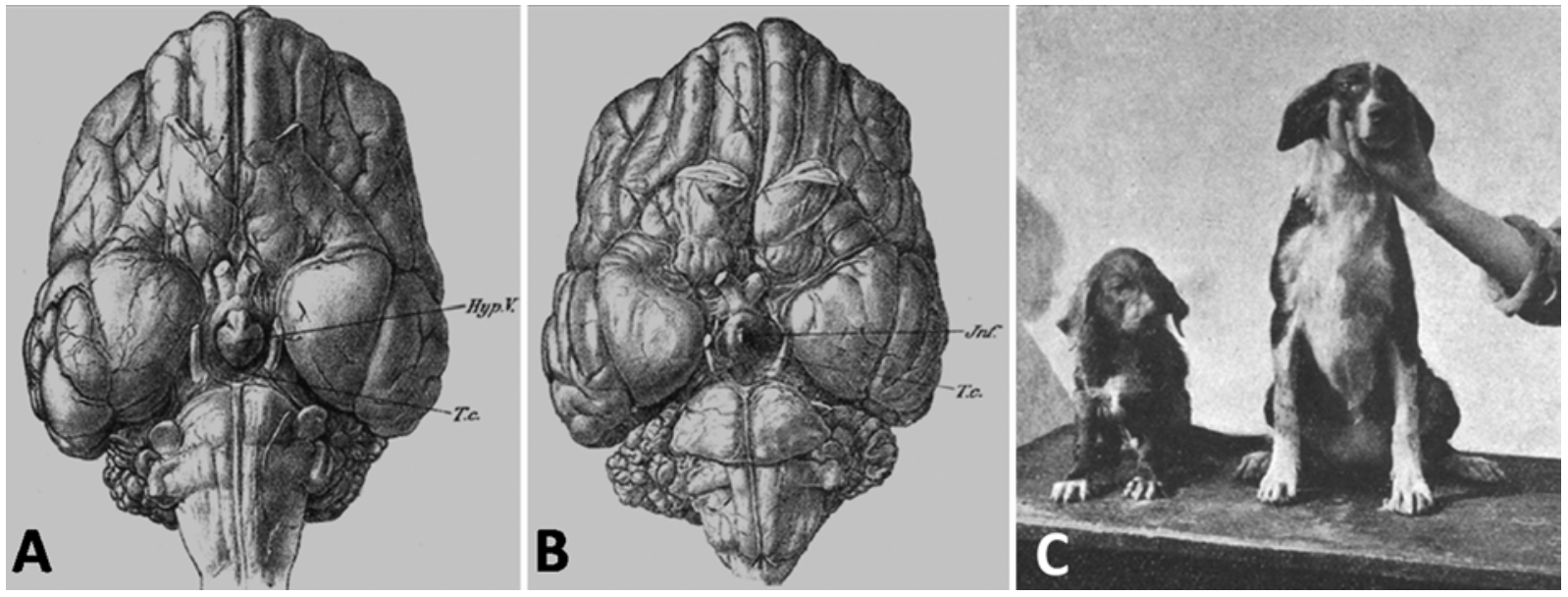

FIG. 13. Surgical procedure of experimental hypophysectomy in dogs through a transpalatal route. A: Anatomical view of the undersurface of the brain before the operation. Note the position of the pituitary gland (Hyp. V.) and the adjacent tuber cinereum (T.C.). B: View of the undersurface of the brain after the operation. Note the stump of the infundibulum (Inf.) and the anatomically intact tuber cinereum (T.c.) after sectioning of the pituitary stalk and removal of the gland through the transpalatal route (compare with anatomical injury to the tuber cinereum after the Paulescu-Cushing subtemporal approach seen in Fig. 14). C: Effects of hypophysectomy without injury to the tuber cinereum: growth is stunted (animal on the left), but the puppy did not show any signs of dullness or lethargy. From Aschner: Pflügers Archiv 146:1-146, 1912

ciated with infundibulotuberal tumors, such as marked daily drowsiness (shown in Fig. 15A, which illustrates the abnormal somnolence observed in another of Cushing's pituitary case patients-Patient No. II in his monograph), forgetfulness, childish behavior, fits of rage, sudden mood swings, abnormal body temperature, and/or gait imbalance, were first observed in Case No. 3, which should be considered the starting point of Cushing's clinical research on the hypothalamus.

Harvey Cushing began to pay particular attention to the behavioral disturbances of his pituitary patients a short time after moving to Peter Bent Brigham Hospital. In-
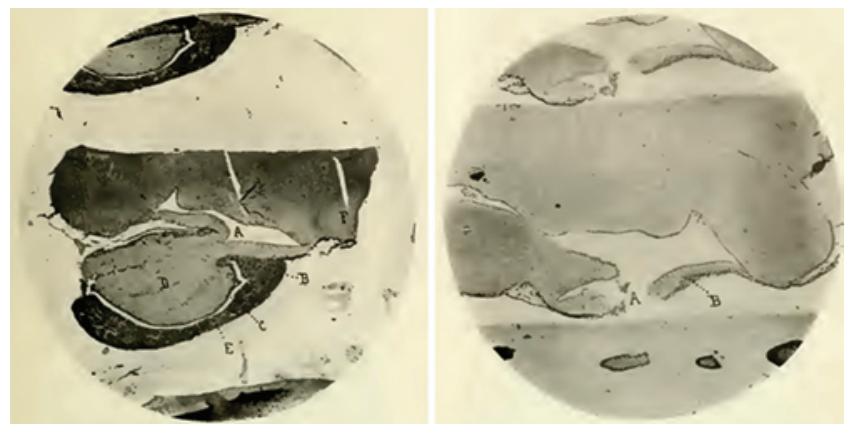

FIG. 14. Histological sections after hypothalamic injury caused by experimental hypophysectomy in dogs. Left: Normal anatomy of the third ventricle floor. Median section through the base of the brain showing the intact pituitary gland. Major structures depicted are third ventricle $(A)$; junction of pars anterior and intermedia of the gland $(B)$; cleft between the pars anterior and the pars nervosa (C); pars nervosa (posterior lobe, $D)$; anterior lobe $(E)$; and optic chiasm (F). The 2 strips of nervous tissue joining the upper central portion of the pars nervosa pituitary with the basal brain correspond to the tuber cinereum, which forms the floor of the third ventricle (gray nervous tissue on both sides below A). Right: Effects of hypophysectomy. Median section through the base of the brain 4 days after total hypophysectomy. Note the breach at the level of the third ventricle floor $(A)$ and the anatomical injury to the adjacent tuber cinereum on both sides of the breach (B). From Crowe: Johns Hopkins Hosp Bull 21:127-169, 1910. trigued by the noticeable daily drowsiness and strange behavior manifested by many of his patients with Fröhlich's syndrome, he delivered an address to psychiatrists about this subject in April 1913, on the occasion of the opening of the Henry Phipps Psychiatric Clinic in Baltimore. The written transcript of this address constitutes the first complete account of hypothalamic alterations caused by infundibular tumors published in the medical literature in the 20th century. ${ }^{32}$ At that moment, Cushing assumed that psychological alterations associated with adiposogenital dystrophy were due to pituitary secretion insufficiency rather than hypothalamic dysfunction. According to his theory of the passage of pituitary gland secretions into

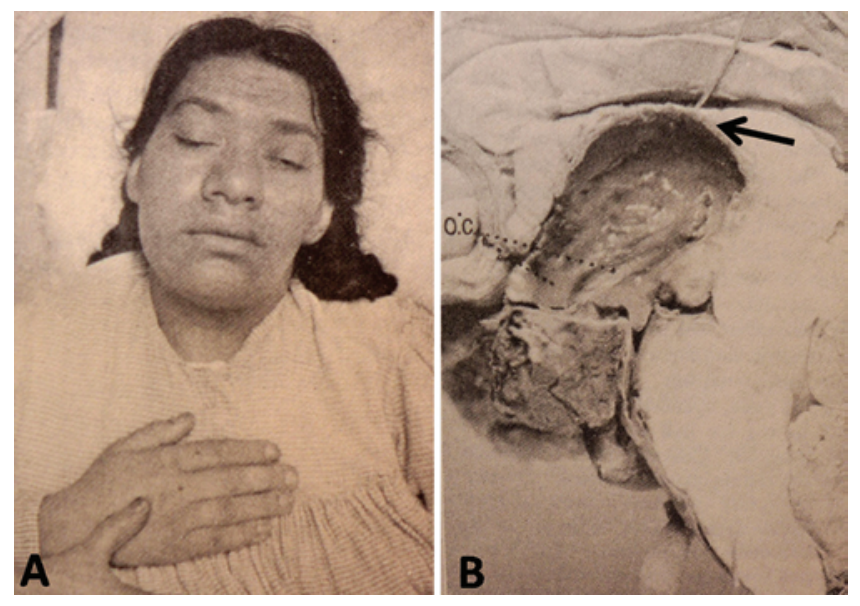

FIG. 15. Abnormal somnolence associated with anatomical distortions of the infundibulotuberal region of the hypothalamus. A: Photograph of 26 -year-old woman with amenorrhea, excessive drowsiness, and typical signs of acromegaly treated by Harvey Cushing in June 1910 (Case II in Cushing's pituitary monograph). B: Median section of the brain showing a large pituitary tumor (macroadenoma) found at the patient's autopsy. Note how this tumor encroaches upon the hypothalamus (indicated by the arrow), between the optic chiasm (O.C.) and the mammillary bodies. 
the third ventricle, infundibular tumors would cause hypersomnia by blocking or interrupting such passage, preventing CSF replenishment of certain kinds of elements essential for cortical activity. ${ }^{36}$

Ultimately, the most conclusive evidence supporting Cushing's belief in glandular insufficiency as a major cause of drowsiness came from his clinical experiments with pituitary gland implantation. On February 9, 1912, Cushing implanted the pituitary gland of a stillborn into the subcortex of an adult patient with Fröhlich's syndrome, severe somnolence, and forgetfulness. An unexpected and astonishing improvement in his mental condition occurred, and the patient could be discharged from the hospital, fully alert and oriented to time and place. ${ }^{32}$ Although the effects of this therapy were only temporary and the patient finally succumbed in a lethargic state (at the autopsy an infundibular papillary $\mathrm{CP}$ was found), Cushing's experience with whole pituitary gland implants and injections of hypophyseal extracts convinced him of the "glandular" cause of somnolence.

Despite all these claims, Cushing also admitted that, unquestionably, gradual pressure deformations of the third ventricle floor caused by large pituitary tumors and infundibular CPs could also be implicated in the genesis of psychiatric disturbances such as disorientation, overfamiliarity, facetiousness, and a peculiar indifference to the malady the patient was suffering from. ${ }^{31}$ Cushing emphasized that it was not at all surprising that pathologists (he did not mention Erdheim by name, but he was certainly alluding to him) who found congenital tumors in the interpeduncular space had postulated the existence of centers for somnolence, diuresis, and obesity in the tuber cinereum to which they attributed the above-mentioned symptoms..$^{20,32,77}$ It was John Fulton and Percival Bailey who brought Cushing's concepts up to date in 1929 when they demonstrated that somnolence and behavioral alterations caused by infundibular/third-ventricle tumors had a common origin in functional disturbances of the hypothalamus. ${ }^{44}$ Three years later, at the end of his career as a neurosurgeon, Harvey Cushing finally declared his acceptance of the new physiological paradigm of loss of hypothalamic control over the pituitary gland and inner body homeostasis as a primary cause of symptoms associated with infundibular tumors. ${ }^{30}$

\section{Conclusions}

At the turn of the 20th century, clinical attention focused on the functional roles of the pituitary gland and the hypothalamus with the recognition of a new syndrome of obesity and sexual immaturity associated with interpeduncular or suprasellar cysts, known as Fröhlich's syndrome. The syndrome was observed in two adolescent patients of similar ages, a boy and a girl, attended toward the end of 1901 by Alfred Fröhlich in Vienna and Harvey Cushing in Baltimore, respectively. In an amazing twist of fate the two physicians had met while working as visiting scientists in Sherrington's laboratory and had become good friends. Cushing's interpeduncular tumor was found at the autopsy of a 16-year-old girl called Mary D. The tumor was diagnosed by William Welch as a "teratoma" and reported as
Pituitary Case No. 3 in Cushing's monograph. This lesion probably corresponded to an infundibulotuberal $\mathrm{CP}$ and largely influenced Cushing's concepts on altered states of the pituitary gland and also his determination to start a career as a pituitary surgeon. The category of infundibular tumors, and particularly the subgroup of CPs involving the hypothalamus, would become one of the most baffling problems Cushing confronted as a neurosurgeon. Ultimately, Mary D.'s case provided the impetus for the creation of the Harvey Cushing Brain Tumor Registry, Cushing's major legacy to the fields of neurosurgery and neuropathology.

\section{Acknowledgments}

We wish to especially thank Crystal Smith, Reference Librarian of the Department of History of Medicine at the National Library of Medicine, National Institutes of Health, Bethesda, Maryland, for her kind assistance during the process of searching and retrieving articles and monographs used in this study. We are also indebted to Lucretia MacLure and all the staff at the Francis Countway Library of Medicine at Harvard Medical School, Boston, Massachusetts, for their invaluable help in obtaining some of the original research material used for this study. Finally, the authors wish to express their gratitude to George Hamilton for his critical review of the language and style of the manuscript.

This study was supported by the Sixto Obrador Award from the Spanish Society of Neurosurgery (SENEC) granted to the best national research study of Neurosurgery in 2013.

\section{References}

1. Anderson E: Earlier ideas of hypothalamic function, including irrelevant concepts, in Haymaker W, Anderson E, Nauta WJH (eds): The Hypothalamus. Springfield, IL: Charles C. Thomas, 1969, pp 1-12

2. Anderson E, Haymaker W: Breakthroughs in hypothalamic and pituitary research, in Swaab DF, Schade JP (eds):

Integrative Hypothalamic Activity. Amsterdam: Elselvier, 1974, pp 1-70

3. Aschner B: Über die function der hypophyse. Pflugers Arch 146:1-146, 1912

4. Babinski MJ: Tumeur du corps pituitaire sans acromégalie et avec arrèt de développement des organs génitaux. Rev Neurol 8:531-533, 1900

5. Bailey P: Tumors involving the hypothalamus and their clinical manifestations, in Fulton JF, Ranson SW, Frantz AM (eds): The Hypothalamus and Central Levels of Autonomic Function. Baltimore: Williams \& Wilkins, 1940, p 713-724

6. Bailey P, Bremer F: Experimental diabetes insipidus. Arch Intern Med 28:773-803, 1921

7. Beadles CF: Malignant disease at the base of the skull, involving the pituitary fossa (two cases). Trans Pathol Soc London 46:172-184, 1895

8. Beck H: Ueber ein teratom der hypophysis cerebri. Zeitschrift Heilkunde 4:393-409, 1883

9. Beckmann JW, Kubie LS: A clinical study of twenty-one cases of tumors of the hypophyseal stalk. Brain 52:127170,1929

10. Benda C: Beiträge zur normalen und pathologischen Histologie der menschlichen Hypophysis Cerebri. Berl Klin Wochenschr 37:1205-1210, 1900

11. Biedl A: Innere Sekretion. Ihre Physiologischen Grundlagen und Ihre Bedeutung für die Pathologie. Vienna: Urban \& Schwarzenberg, 1913

12. Bliss M: Harvey Cushing. A Life in Surgery. New York: Oxford University Press, 2005

13. Bonin G: Classification of tumors of the pituitary body. BMJ 2:934, 1913 
14. Bowlby AA: Tumour of the pituitary body. Trans Pathol Soc London 36:35, 1885

15. Boyce R, Beadles CF: A further contribution to the study of the pathology of the hypophysis cerebri. J Pathol Bacteriol 1:359-383, 1893

16. Bramwell B: Intracranial Tumors. Edinburgh: Young J Pentland, 1888

17. Bruch H: The Fröhlich syndrome. Report of the original case. Am J Dis Child 58:1282-1289, 1939

18. Brydon HL: Intracranial dermoid cysts with nasal dermal sinuses. Acta Neurochir (Wien) 118: 185-188, 1992

19. Camus J, Roussy G: Polyurie expérimentale par lésions de la base du cerveau. La polyurie dite hypophysaire. C R Seances Soc Biol Fil 75:628-633, 1913

20. Castro-Dufourny I, Carrasco R, Prieto R, Barrios L, Pascual JM: The infundíbulo-tuberal síndrome caused by craniopharyngiomas: clinic-pathological evidence from an historical French cohort (1705-1973). Pituitary 18:642-657, 2015

21. Cohen-Gadol AA, Laws ER, Spencer DD, De Salles AAF: The evolution of Harvey Cushing's surgical approach to pituitary tumors from transsphenoidal to transfrontal. J Neurosurg 103:372-377, 2005

22. Cohen-Gadol AA, Spencer DD (eds): The Legacy of Harvey Cushing. Profiles of Patient Care. New York: Thieme, 2007, pp 1-93

23. Critchley M, Ironside RN: The pituitary adamantinomata. Brain 49:437-481, 1926

24. Crowe SJ, Cushing H, Homans J: Experimental hypophysectomy. Johns Hopkins Hosp Bull 21:127-169, 1910

25. Cushing H: The chiasmal syndrome of primary optic atrophy and bitemporal field defects in adults with normal sella turcica. Arch Ophtalmol (Paris) 3:505-551, 1930

26. Cushing H: "Dyspituitarism": twenty years later: with special consideration of the pituitary adenomas. Arch Intern Med (Chic) 51:487-557, 1933

27. Cushing H: The establishment of cerebral hernia as a decompressive measure for inaccessible brain tumors; with the description of intermuscular methods of making the bone defect in temporal and occipital regions. Surg Gynecol Obstet 1:297-314, 1905

28. Cushing H: The hypophysis cerebri: clinical aspects of hyperpituitarism and of hypopituitarism. JAMA 53:249255, 1909

29. Cushing H: Intracranial Tumors. Notes upon a series of two thousand verified cases with surgical mortality percentages pertaining thereto. Springfield, IL: Charles C. Thomas, 1932, pp 93-98

30. Cushing H: Papers relating to the pituitary body, hypothalamus and parasympathetic nervous system. Baltimore: Charles C Thomas, 1932

31. Cushing H: The Pituitary Body and Its Disorders. Philadelphia: JB Lippincott, 1912

32. Cushing H: Psychic disturbances associated with disorders of the ductless glands. Am J Insanity 69:965-990, 1913

33. Cushing H: Sexual infantilism with optic atrophy in cases of tumor affecting the hypophysis cerebri. J Nerv Ment Dis 33:704-716, 1906

34. Cushing H: Surgery of the head, in Keen WW (ed): Surgery. Its Principles and Practice. Philadelphia: W.B. Saunders Company, 1911, pp 17-276

35. Cushing H: Surgical experiences with pituitary disorders. JAMA 63: $1515-1525,1914$

36. Cushing H, Goetsch E: Concerning the secretion of the infundibular lobe of the pituitary body and its presence in the cerebrospinal fluid. Am J Physiol 27:60-86, 1910

37. Erdheim J: Uber Hypophysengangsgeschwulste und Hirmcholesteatome. Sitzungsb Kais Akad Wissen Math Naturw Klin 113:537-726, 1904

38. Fahr T: Demonstration eines papilloms an der basis des 3 . Hirnventrikels. Munch Med Wochenschr 50:1987, 1903
39. Falta W: The Ductless Glandular Diseases, ed 2. Meyers MK, trans. Philadelphia: Blakiston's Son \& Co, 1916

40. Farnell FJ: An extracerebral tumor in the region of the hypophysis. N Y Med J 90:462-465, 1911

41. Fröhlich A: Ein fall von tumor der hypophysis cerebri ohne akromegalie. Wien Klin Rundschau 15: 883-886, 906908, 1901

42. Fröhlich A: Discussion, in Fulton JF, Ranson SW, Frantz AM (eds): The Hypothalamus and Central Levels of Autonomic Function. Baltimore: Williams \& Wilkins, Baltimore, 1940, p 722

43. Fulton JF: Harvey Cushing. A Biography. Springfield, IL: Charles C. Thomas, 1946, p 163

44. Fulton JF, Bailey P: Contribution to the study of tumors in the region of the third ventricle: their diagnosis and relation to pathological sleep. J Nerv Mental Dis 69:1-25, 145-164, 261-277, 1929

45. Globus JH: Teratoid cyst of the hypophysis. Arch Neurol Psychiatry 9:417-430, 1923

46. Globus JH, Gang KM: Craniopharyngeoma and suprasellar adamantinoma. J Mt Sinai Hosp 12:220-276, 1945

47. Goetsch E, Cushing H, Jacobson C: Carbohydrate tolerance and the posterior lobe of the hypophysis cerebri. An experimental and clinical study. Johns Hopkins Hosp Bull 22:190-195, 1911

48. Gorlin RJ, Chaudhry AP: The ameloblastoma and the craniopharyngioma; their similarities and differences. Oral Surg Oral Med Oral Pathol 12:199-205, 1959

49. Greenblatt SH: The crucial decade: modern neurosurgery's definitive development in Harvey Cushing's early research and practice, 1900 to 1910. J Neurosurg 87:964-971, 1997

50. Greep RO: History of research on anterior hypophysial hormones, in Knobil E, Sawyer WH (eds): Handbook of Physiology. A critical, comprehensive presentation of physiological knowledge and concepts. Section 7: Endocrinology, Vol IV: The pituitary gland and its neuroendocrine control, Part 1. Washington, DC: American Physiological Society, 1974, pp 1-27

51. Halstead AE: Remarks on the operative treatment of tumors of the hypophysis - with the report of two cases operated on by an oro-nasal method. Surg Gynecol Obstet 10:494-502, 1910

52. Harrison MJ, Morgello S, Post KD: Epithelial cystic lesions of the sellar and parasellar region: a continuum of ectodermal derivatives? J Neurosurg 80:1018-1025, 1994

53. Hecht D: A teratoma of the hypophysis. JAMA 53:10011005, 1909

54. Herring PT: The histological appearances of the mammalian pituitary body. Q J Exp Physiol 1:121-159, 1908

55. Horsley V: Brown Lectures III. Functional nervous disorders due to loss of thyroid gland and pituitary body. Lancet 1:3-5, 1886

56. Horsley V: A paper on optic neuritis, choked disc, or papilloedema: treatment, localizing value, and pathology. BMJ 1:553-558, 1910

57. Howell WH: The physiological effects of extracts of the hypophysis cerebri and infundibular body. J Exp Med 3:245-258, 1898

58. Ingraham FD, Bailey OT: Cystic teratomas and teratoid tumors of the central nervous system in infancy and childhood. J Neurosurg 3:511-532, 1946

59. Jackson H: Craniopharyngeal duct tumors. JAMA 66:10821084, 1916

60. Johnson HC: Surgery of the hypophysis, in Walker AE (ed): A History of Neurological Surgery. Baltimore: Williams \& Wilkins, 1952, pp 152-177

61. Kalnins V: Calcification and amelogenesis in craniopharyngiomas. Oral Surg Oral Med Oral Pathol 31:366-379, 1971 
62. Kanavel AB: The removal of tumors of the pituitary body by an infranasal route. A proposed operation with a description of the technic. JAMA 53:1704-1707, 1909

63. Konovalov AN, Lichterman BL, Korshunov AG: Endosuprasellar teratoma with teeth formation. Case report. Acta Neurochir (Wien) 118:181-184, 1992

64. Kraus EJ: Über ein epignathisches teratom der hypophysengegend. Virchows Arch 271:546-555, 1929

65. Kreir F, Swaab DF: History of neuroendocrinology: The spring of primitive existence, in Finger S, Boller F, Tyler KL (eds): Handbook of Clinical Neurology. Amsterdan: Elselvier, 2010, pp 335-360

66. Lindholm J: A century of pituitary surgery: Schloffer's legacy. Neurosurgery 61:865-868, 2007

67. McKenzie KG, Sosman MC: The roentgenological diagnosis of craniopharyngeal pouch tumors. AJR Am J Roentgenol 11:171-176, 1924

68. Medvei VC: A History of Endocrinology. Lancaster: MTP Press Limited, 1982

69. Merchut MP, Biller J, Ghobrial M, Fine M: Adult intrasellar teratoid tumor. J Clin Neuroophthalmol 6:175-180, 1986

70. Miller R: Dystrophia adiposo-genitalis bei hypophysengangscyste. Virchows Arch Pathol Anat 236:207-224, 1922

71. Oberndorfer S: Hypophysen- und hypophysengegendtumoren. Munch Med Wochenschr 67:946-947, 1920

72. Oliver G, Schäfer EA: On the physiological action of extracts of pituitary body and certain other glandular organs. J Physiol 18:277-279, 1895

73. Onanoff J: Sur un cas d'epithélioma (étude histologique). Thèse, Faculté de Médecine de Paris. Paris, Ollier-Henry, 1892

74. Palaoğlu S, Akbay A, Mocan G, Önol B, Özcan OE, Özgen $\mathrm{T}$, et al: Ossified adamantinomatous type craniopharyngiomas. A series of 13 patients. Acta Neurochir (Wien) 127:166-169, 1994

75. Pascual JM, Carrasco R, Prieto R, Gonzalez-Llanos F, Alvarez F, Roda JM: Craniopharyngioma classification. J Neurosurg 109:1180-1183, 2008 (Letter)

76. Pascual JM, González-Llanos F, Barrios L, Roda JM: Intraventricular craniopharyngiomas: topographical classification and surgical approach selection based on an extensive overview. Acta Neurochir (Wien) 146:785-802, 2004

77. Pascual JM, Prieto R, Carrasco R: Infundibulo-tuberal or not strictly intraventricular craniopharyngioma: evidence for a major topographical category. Acta Neurochir (Wien) 153:2403-2426, 2011

78. Pascual JM, Prieto R, Carrasco R, Barrios L: Displacement of mammillary bodies by craniopharyngiomas involving the third ventricle: surgical-MRI correlation and use in topographical diagnosis. J Neurosurg 119:381-405, 2013

79. Pascual JM, Prieto R, Castro-Dufourny I, Carrasco R, Strauss S, Barrios L: Development of intracranial approaches for craniopharyngiomas: an analysis of the first 160 historical procedures. Neurosurg Focus 36(4):E13, 2014

80. Pascual JM, Prieto R, Mazzarello P: Sir Victor Horsley: pioneer craniopharyngioma surgeon. J Neurosurg 123:39-51, 2015

81. Pascual JM, Prieto R, Navas M, Carrasco R: Conquest of third ventricle craniopharyngiomas. J Neurosurg 112:1156-1161, 2010 (Letter)

82. Paulescu NC: L'Hypophyse du Cerveau. Paris: Vigot Frères, 1908

83. Prieto R, Pascual JM: Craniopharyngiomas with a mixed histological pattern: the missing link to the intriguing pathogenesis of adamantinomatous and squamous-papillary varieties? Neuropathology 33:682-686, 2013

84. Prieto R, Pascual JM, Barrios L: Optic chiasm distortions caused by craniopharyngiomas. Clinical-MRI correlation and influence on visual outcome. World Neurosurg 83:500-529, 2015
85. Reford LL, Cushing H: Is the pituitary gland essential to the maintenance of life? Johns Hopkins Hop Bull 20:105-107, 1909

86. Rosegay H: Cushing's legacy to transsphenoidal surgery. J Neurosurg 54:448-454, 1981

87. Rossi A, Cama A, Consales A, Gandolfo C, Garrè ML, Milanaccio C, et al: Neuroimaging of pediatric craniopharyngiomas: a pictorial essay. J Pediatr Endocrinol Metab 19 (1 Suppl 1):299-319, 2006

88. Rushing EJ, Giangaspero F, Paulus W, Burger PC: Craniopharyngioma, in Louis DN, Ohgaki H, Wiestler OD, et al (eds): WHO Classification of Tumors of the Central Nervous System, 4th ed. Lyon, France: IARC, 2007, pp 238-240

89. Sainsbury H: Tumour of the base of the brain showing the structure of skin and subcutaneous tissue. Trans Path Soc London 37:57-59, 1886

90. Seemayer TA, Blundell JS, Wiglesworth FW: Pituitary craniopharyngioma with tooth formation. Cancer 29:423-430, 1972

91. Stumpf: Demonstration eines tumors des III hirnventrikels. Centralblatt Allgem Pathol Pathol Anat 21:1001, 1910

92. von Eiselsberg AF: Operations upon the hypophysis. Ann Surg 52:1-14, 1910

93. von Eiselsberg AF, von Frankl-Hochwart L: Über operative behandlung der tumoren der hypophysengegend. Neurol Centralb 26:994-1001, 1907

94. Wahl CJ: The Harvey Cushing Brain Tumor Registry: changing scientific and philosophic paradigms and the study and preservation of archives [thesis]. New Haven, CT: Yale University, 1996

95. Wahl CJ, Tubbs RS, Spencer DD, Cohen-Gadol AA: Harvey Cushing as a book collector, bibliophile, and archivist: the precedence for the genesis of the Brain Tumor Registry. Historical vignette. J Neurosurg 111:1091-1095, 2009

96. Walker JWT: A case of primary osteoma of the brain. Rep Soc Study Dis Child 2:173-190, 1902

97. Warthin AS: A study of the lipin content of the liver in two cases of dyspituitarism. J Lab Clin Med 2:73-93, 1916

98. White WH: A myo-neuroma of the pituitary body. Trans Pathol Soc London 36:37-38, 1885

99. Zada G, Lin N, Ojerholm E, Ramkissoon S, Laws ER: Craniopharyngioma and other cystic epithelial lesions of the sellar region: a review of clinical, imaging, and histopathological relationships. Neurosurg Focus 28(4):E4, 2010

100. Zülch KJ: Atlas of Gross Neurosurgical Pathology. New York: Springer, pp 161-163, 1975

\section{Disclosures}

The authors report no conflict of interest concerning the material or methods used in this study or the findings described in this paper.

\section{Author Contributions}

Conception and design: Pascual. Acquisition of data: both authors. Analysis and interpretation of data: both authors. Drafting the article: both authors. Critically revising the article: both authors. Reviewed submitted version of manuscript: both authors. Approved the final version of the manuscript on behalf of both authors: Pascual.

\section{Correspondence}

José María Pascual, Department of Neurosurgery, La Princesa University Hospital, C/ Diego de León 62, Madrid 28006, Spain. email: jmpascual@iib.uam.es. 